\title{
Two Thousand New, Million-Person Cities by 2050 - We Can Do It!
}

\author{
E. Stephen GOLDIE, RFD, BTP, MPIA, MCNU
}

City Planning Advisor, Abu Dhabi Department of Urban Planning \& Municipalities, UAE

\begin{abstract}
In 1950 three quarters of a billion people lived in large towns and cities, or 30\% of the total world population of over 2.5 billion. By 2009 this had grown to 3.42 billion, just over half of a total population of over 6.8 billion. The United Nations Secretariat currently forecasts that in 20506.4 billion, 67\% of a total of almost 9.6 billion people will live in urban areas.

Just over a third of that growth, around one billion people, is expected to be in China, India and Nigeria, but the remaining two billion will be in the countries around those countries: a massive arc stretching across the world from West Africa through the Middle East, across Asia and into the Pacific.

In these other countries, an additional two billion urban residents over thirty years translates into a need to build a new city for a population of one million people, complete with hospitals, schools, workplaces, recreation and all the rest, at a rate of more than four a month: 2000 cities, in countries with little urban planning capability!

In addition, the United Nations' sustainable development goals (SDGs) include goal 11: Sustainable Cities \& Communities "Make cities and human settlements inclusive, safe, resilient and sustainable", so these new cities should demonstrate a level of planning competence and city management ability that many towns and cities in the world are struggling to achieve.
\end{abstract}

Notwithstanding the scale of the problem, the size and cost of the planning effort is demonstrated to be feasible, provided that action is swift and new technologies are developed and applied to the planning and approvals processes.

Of course, taking these plans to construction is a much bigger effort, but the economy of cities is strongly circular, meaning that the initial cash injection generates jobs that pay wages that are spent on rent and goods within the city, which then generate profits that fund developments that generate jobs, etc. However, this requires good governance, a planning consideration that must also be addressed if the full benefits of planning, designing and building 2000 cities in the Third World are to be enjoyed by the citizens of those cities.

Finally, failure is not an option, because "If we don't solve this equation, it is not that people will stop coming to cities. They will come anyhow, but they will live in slums, favelas and informal settlements" (Arevena, 2014), and we know that slums the world over produce crime, refugees and revolution, and then export these problems internationally, one way or another. The world most certainly does not want more refugees or another Syria, so planners must rescue us from that future, before it happens! 


\section{Keywords}

Rapid massive third-world, urbanisation, RAMTU, SDG 11, transect planning, artificial intelligence

\section{Introduction}

\subsection{The "3S" menace}

In Portland, Oregon, on 23 October 2017, the keynote speaker to the ISOCARP-UNESCO Special Event to discuss Sustainable Development Goal 11 - Make cities and human settlements inclusive, safe, resilient and sustainable (SDG 11 - Cities) was Ms. Hawa Deme, cofounder of Umuganda Africa. She highlighted that $95 \%$ of future urban expansion will occur in the Third World. The next speaker, Mr. Nicholas You, noted that in the next fifty years, humanity will spend more money on cities than we have cumulatively spent in all of human history, because the quantity of urbanism will double in capacity from 3 billion to 6 billion people (personal notes taken at the event).

The core of the problem is that there will be an additional urban population of 3 billion by 2050. Just over a third of that growth is expected to be in China, India and Nigeria, but the remaining two-thirds will be in the countries around those countries: a great arc of growth stretching from West Africa, through the Middle East, across Asia and into the Pacific. An additional 3 billion urban residents in thirty-three years translates into a need to build a new city for a population of one million people, complete with hospitals, schools, workplaces, recreation and all the rest, at a fantastic rate, and it has to happen in places with low capacity and poor infrastructure. In short, the problem is one of rapid, massive third-world urbanisation (RAMTU). The scale, speed and scarcity of resources required to address this problem are staggering and Chilean architect Alejandro Arevena rightly calls this the "3S Menace":

Let's start with the global challenge of urbanization. It's a fact that people are moving towards cities. and even if counterintuitive, it's good news. Evidence shows that people are better off in cities. But there's a problem that I would call the "3S" menace: The scale, speed, and scarcity of means with which we will have to respond to this phenomenon has no precedence in history. For you to have an idea, out of the three billion people living in cities today, one billion are under the line of poverty. By 2030, out of the five billion people that will be living in cities, two billion are going to be under the line of poverty. That means that we will have to build a one million-person city per week with 10,000 dollars per family during the next 15 years. A one million-person city per week with 10,000 dollars per family. If we don't solve this equation, it is not that people will stop coming to cities. They will come anyhow, but they will live in slums, favelas and informal settlements. [my emphasis] (Arevena, 2014)

Hence, while diplomats and activists must keep us safe from nuclear war, and scientists and engineers must save us from global warming and species extinction, it falls to urban planners to keep the peace through the provision of healthy and harmonious cities for three billion people by 2050, and - as the Emperor Napoleon reportedly said - "We don't have a moment to lose!"

\subsection{Two Thousand New, Million-Person Cities by $\mathbf{2 0 5 0}$}

When the priority is speed the need for effective planning is even greater than usual, because both the planning process and the plan itself must be first class. So, our first task is a plan for 
a program to plan and build new urbanism equivalent to two thousand new, million-person cities by 2050 , in countries with little to no capability for this task.

I have written and/or presented on aspects of this problem and of possible solutions before, but have never previously attempted to prescribe a holistic solution. The earlier papers and presentations are here referenced as:

A. "The Impending Revolution in Urban Planning Practice: Intelligent and automated, but will it be garbage in, garbage out?" (51st ISOCARP Netherlands, 19-23 October 2015)

B. “What's So Special About Special Districts?" (CNU 24, Detroit MI USA, 8-11 June 2016)

C. "Sustainability and the Revolution in Urban Planning" (52nd ISOCARP Congress, Durban, South Africa, 12-16 September 2016)

D. “Smart Planning for Smart Cities" (PIA National Congress, Sydney, NSW, Australia, 35 May 2017).

E. “The Jobless City - Revolution or Paradise?” (53rd ISOCARP Joint Congress, Portland, OR, USA, 24-27 October 2017).

F. "The Periodic Table of Urbanism" (presented at CNU 26, Savannah, USA, 15-19 May 2018 and at ISOCARP, Bodo, Norway, 1-5 October 2018).

These papers and presentations have all been deliberately leading to this point (although not without some serendipity): the feasibility of solving rapid, massive third-world urbanisation (RAMTU). Therefore, this paper relies heavily on parts of these preceding works, but they will only be further referenced where specifically referred to, in order to better emphasise the references to other author's work than my own.

This paper also assumes that the reader is familiar with the principles and practices of the New Urbanism.

\subsection{The New Urbanism}

The true impact of the post-Second World War, Brutalist deflowering of cities everywhere took some time to become apparent, but by the early 1960's writers such as Jane Jacobs (Jacobs, 1961), Herbert Gans (Gans, 1968) and Robert Goodman (Goodman, 1972) were exposing the symptoms. In some cases, they also provided insights into the causes and solutions, but it took another thirty years before the more advanced planners, architects and designers banded together and responded to auto-dominated urban sprawl with practical solutions. In the United States this took the name "The New Urbanism".

The New Urbanism has more than a passing similarity to City Beautiful: "Like New Urbanism, the 19th century [City Beautiful] movement redeemed city planning principles whose influence had waned, and recognized that the design of physical space is important to the identity and cohesiveness of a community." (Stueteville, 2004). In the United Kingdom it does not have a clear name, and is perhaps more a loose alliance of the Prince's Foundation for Building Community, English Partnerships, the now superseded Commission for Architecture and the Built Environment (CABE) and the still active Town and Country Planning Association (TCPA), founded in 1899 by Sir Ebenezer Howard himself. New Urbanist practice is also strong in parts of Australia and New Zealand (personal observation). 
The New Urbanism, and its overseas cousins, have led a gradual roll back of decades of autodependent sprawl while simultaneously (and necessarily) developing a practice that has progressed rapidly from rediscovering the techniques behind the delightful works of past urbanist planners, architects and designers, such as Camillo Sitte, Raymond Unwin and John Nolan, to a body of knowledge and skills that is now well able to plan, design and build sustainable towns and cities: but is it ready for the Digital Revolution?

The description of a whole philosophy of planning is a task requiring many books, not just part of one paper, so I will leave the interested reader to inspect the 1993 Charter of the New Urbanism (Talen, 2013) and then read one of any number of books about the movement. A good place to start is the insightful and witty The Geography of Nowhere: The Rise and Decline of America's Man-Made Landscape (Kunstler, 1993), perhaps followed by the The New Urbanism - Towards an Architecture of Community (Katz, 1994), which provides an excellent, concise, technical introduction and a comprehensive collection of early examples.

\section{Revolution in Urban Planning}

\subsection{An Additional Three Billion People}

Urban planners and designers are faced with the task of housing an additional three billion people in towns and cities by the year 2050 (figure 1). It will be shown later that, not including China, India and Nigeria, this requires the equivalent of 2000 new, one-million person cities to be completed by 2050; the equivalent of building more than six one million-person cities every month for forty years. If climate change displaces another 200 million people, the task will be that much greater (Brown, 2008).

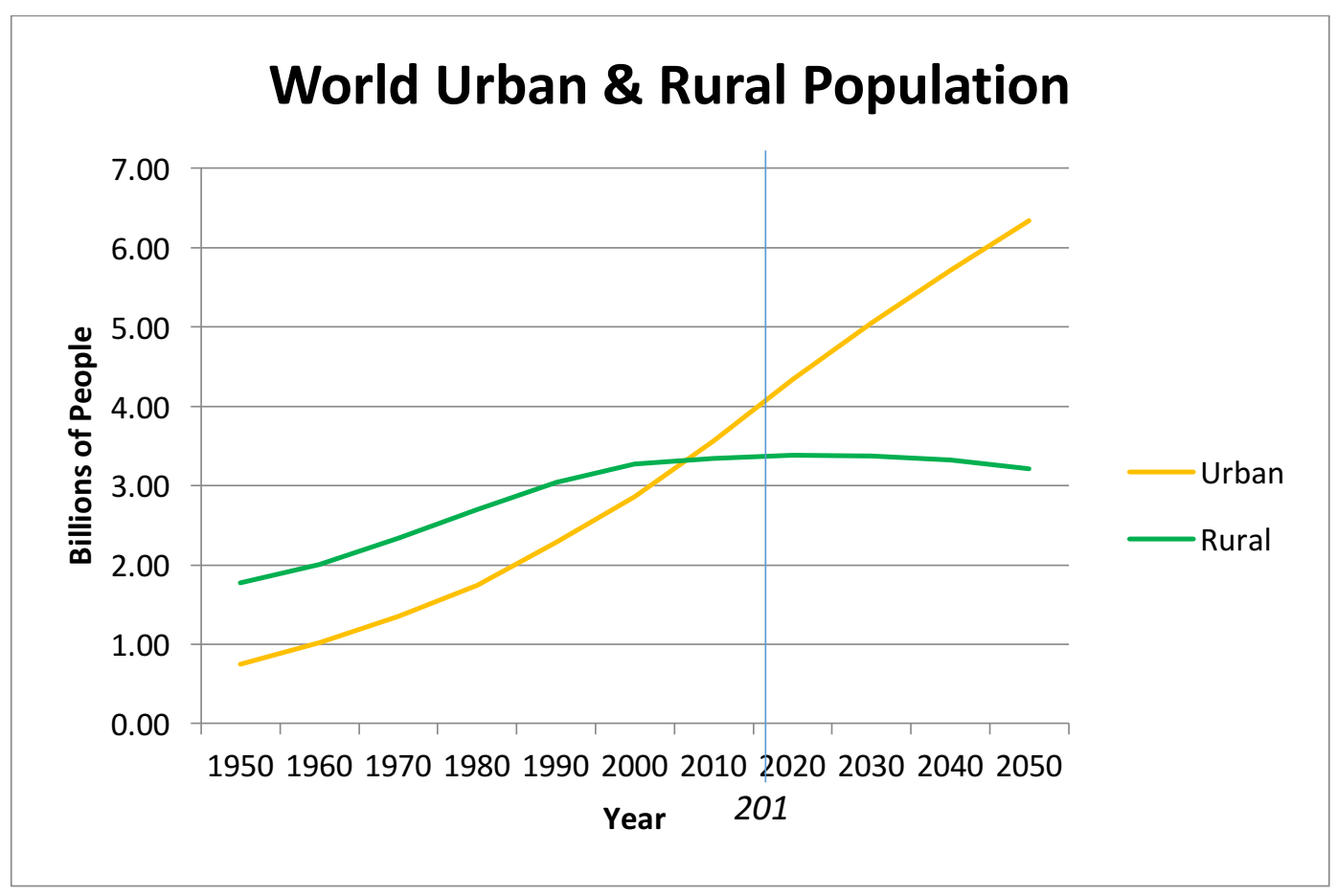

Figure 1: World Urban and Rural Population 1950 to 2015 (United Nations, 2014) 
Compounding this problem, but also demonstrating that it might be part of the solution, the developing economies are generating large scale employment in their urban areas, some 900 million jobs in the thirty years from 1980 to 2010 (figure 2), but most of these jobs require the level of education that only a well-designed and managed large town or a city can provide.

\section{Exhibit E2}

\section{1 billion non-farm jobs were created worldwide in the past 30 years}

\section{Evolution of labor force \\ Million workers ( $\%$ of total)}

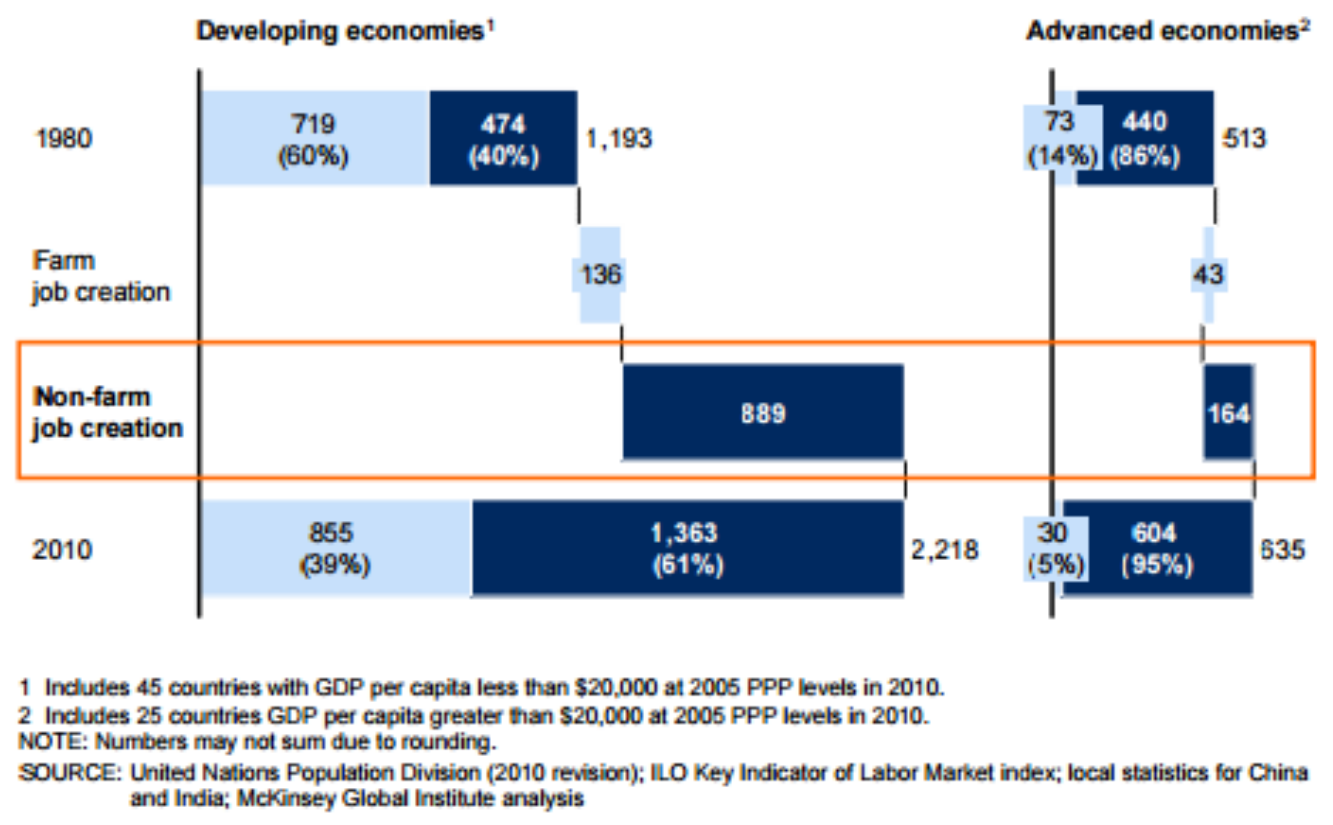

Figure 2: The growth of urban jobs from 1980 to 2010 (Dobbs et al, 2012)

China, since the 1980's, and India more recently have recognised this issue and responded with massive city building or urban improvement programs (World Bank, 2014, p. 3; Vikram, 2014), but only one-third of the additional three billion new urban dwellers are expected to be in China, India and Nigeria, the remaining two-thirds will be in the countries around those countries: a great arc of growth stretching from West Africa, through the Middle East, across Asia and into the Pacific.

Clearly, if massive new urban areas are required very quickly, then a plan that previously took the best part of a decade to prepare will now need to be completed in a tenth of that time. The planning process must therefore move from "slow and ponderous" to "fast and reliable", and must be conducted by efficient, well-managed planning agencies and at least equally competent consultants. This requires not only the adoption of all that the new technologies have to offer, but also the development of a plan-making paradigm that optimises the application of that technology in a way that produces good urbanism. In short, a planning paradigm that avoids the possibility of "garbage in, garbage out".

Over the last quarter century, the most significant advances in the understanding of urban areas, the practice of producing good urban planning and sustainable built outcomes, has 
come from the practitioners and academics who constitute the movement known as the New Urbanism. Three of these advances, the charrette, form-based codes and transect planning are particularly relevant. Many planners are already familiar with the two-fold improvement in efficiency that a good charrette process provides. Firstly, by shortening the plan making process through simultaneously interactive and iterative plan preparation and secondly by increasing the level of support for the plan across all stakeholders and concerned citizens, thereby shortening the approval process.

However, it is the combination of transect-based planning and form based codes that, in my opinion, gives the opportunity to develop the New Urbanism further towards a systemisation that simultaneously enables localisation, which is, perhaps, the core conundrum of urban planning across the ages. Success will enable automation of the approvals process with the possibility of greater than eighty percent of applications being approved, almost instantaneously, on-line. The development of current transect-based planning practice toward this end is discussed in detail later in this paper.

If it is feasible to shorten the plan making process and the development approvals process then perhaps we can, collectively as a profession, enable from now to the year 2050 an additional three billion people to live, learn, work and play in good, new cities and towns. Perhaps some of these cities will even stand the test of time and become the great cities of the Twenty-first Century!

Of course, "stand the test of time" is on old form of words, the modern equivalent is "to be sustainable". I will briefly address the strengths and failings of "sustainability' later, first it is important to consider the alternate case, unsustainability, particularly, in its worst case scenarios.

\subsection{The Limits to Growth}

Whether history will refer to our current era as the $4^{\text {th }}$ Industrial Revolution, the Digital Revolution, the Information Age or something else is not the concern of urban planners. What is important is that there will continue to be a civilisation with historians and philosophers who have the time and the inclination to argue about such things, because the alternatives are most likely:

- Mutually assured destruction by nuclear weapons (Caldicott, 2017);

- Mismanagement of the environment, leading to a sixth great extinction that will eventually include homo sapiens sapiens (Kolbert, 2014; Ceballos, Erlich and Dirzo, 2017, p. 7); and/or

- Mass migration, revolution and war through inadequate responses to rapid, massive $3^{\text {rd }}$ World urbanisation.

Collectively, we can refer to these as the "Limits to Growth" which have long been forecast to reach criticality in the middle of this century (Meadows et al, 1972), and which, if not overcome will lead to either no human civilization, no humans, or no planet at all. We are all, right now, part of an experiment in survival that is clearly not one that any sane person would want to see played out on their own species and on their own planet.

While the first two of humanity's limits to growth are well understood, the third, rapid, massive third-world urbanisation (RAMTU), as outlined above, is probably only common knowledge amongst urban planners, and some staff of the United Nations and related agencies. 
It is a sorry testimony to the accuracy of the analysis conducted by Donella $\mathrm{H}$. Meadows, Dennis L. Meadows, Jørgen Randers, and William W. Behrens III in Limits to Growth (Meadows et al, 1972), that 2050, when two-thirds of the people on this planet will live in towns and cities, is our collective date with destiny: the year of the demise of our civilisation that they warned us of almost half a century ago.

There are therefore now only two key questions for our profession:

1. Is it feasible to plan and construct the equivalent to two thousand new, millionperson, sustainable cities, in countries with little to no capability for this task, by 2050; and, if the answer is yes,

2. Will we try?

In this paper I will answer the first question in the affirmative, but the second question requires a collective will that I have not previously seen demonstrated by our profession. Clearly, this is our last chance to discover it in ourselves.

\section{Sustainability and the Revolution in Urban Planning}

\subsection{The Triple Bottom Line}

Sustainability is usually illustrated by the three-circle 'Triple Bottom Line Model' Venn diagram, representing the three dimensions of sustainability (figure 3 ). It is a simple, but powerful model that has changed the paradigm and inspired people the world over to strive to create a more sustainable society.

While the concept of sustainability is vital if humanity is to survive past the middle of this century (Wheeler, 2013, p71) and its diagrammatic representation as three overlapping circles (a.k.a. the Sustainability Model) has been useful in promoting an understanding of what is required, the fact remains that of itself the diagram provides no immediate guidance decision making. In every case the decision maker, or his/er advisers, must analyse the detailed impacts of not only the proposal, but every facet of the proposal.

For example, how does the Sustainability Model guide a choice between the options shown in figure 4 ? The answer, of course is

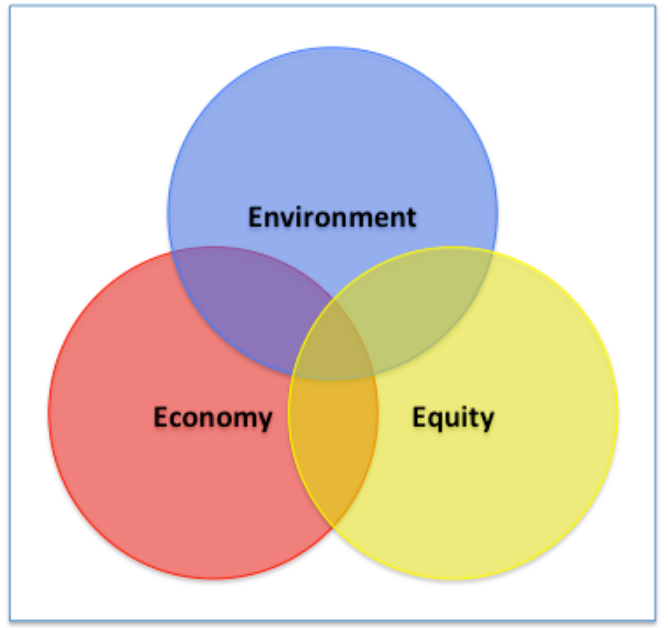

Figure 3: The Sustainability Diagram (Carter and Moir, 2012, p3; Wheeler, 2013).

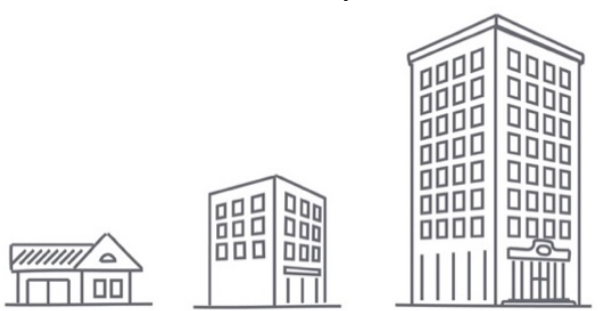

Figure 4: House, Apartment, or highrise? ${ }^{\circledR}$ Agatus: Image ID: 343732052 that of itself, it cannot. To make even a simple decision like this recourse must be had to a long list of interrelated factors requiring extensive study and consideration. 
However, by mapping sustainability, not as a Venn diagram of concepts, but as real things (figure 5) and then expressing the relationships between these things in an interaction model (figure 6) the inherent tension between the natural and built environments is revealed: the built environment exploits the natural environment in order to maintain the economy and improve equity for "the people".

This creates a 'tug of war' between two opposing 'goods' (i.e. it is good to protect the natural environment and it is good to provide for people by way of an economic and equitable built environment), but the difficulty of finding the sustainable middle

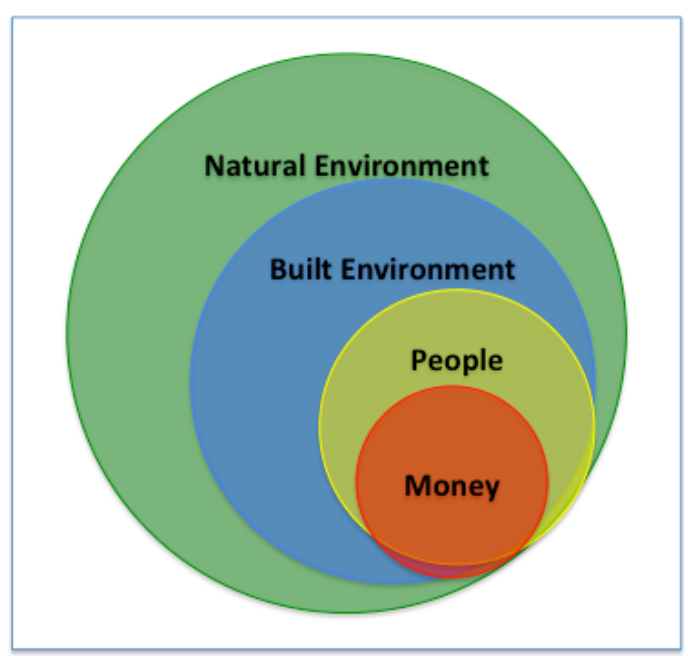

Figure 5: The four factors of sustainability as physical things. ground has led to the development of two opposing camps, respectively pro and antidevelopment. Short term 'wins' for one side over the other encourages the feud to continue, resulting in long-term losses for society as a whole. We need to resolve this conflict, so that we can work together to resolve the existential crisis specified above.

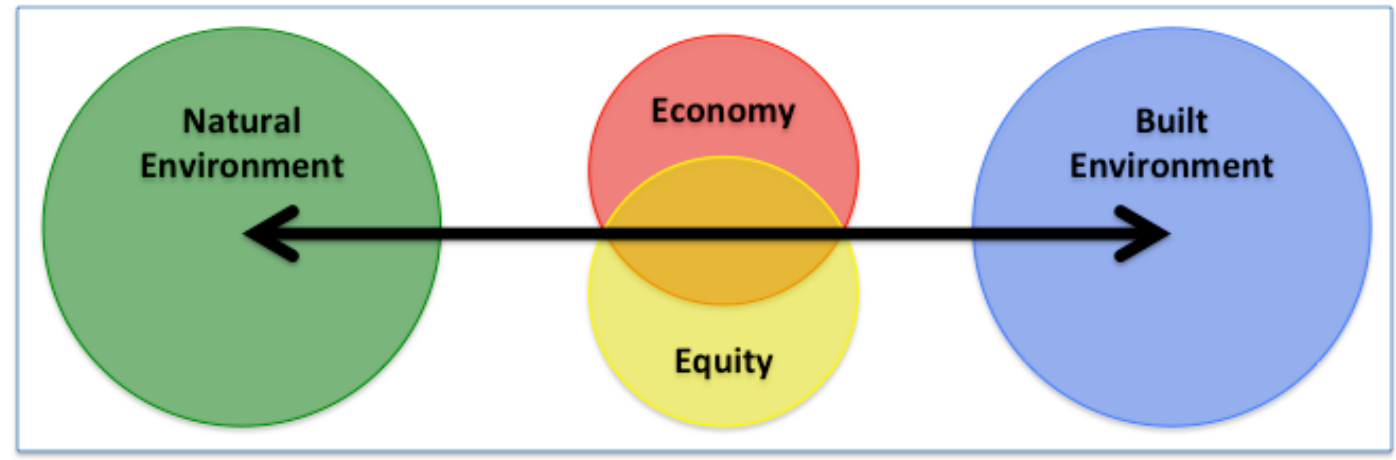

Figure 6: The four factors of sustainability in tension.

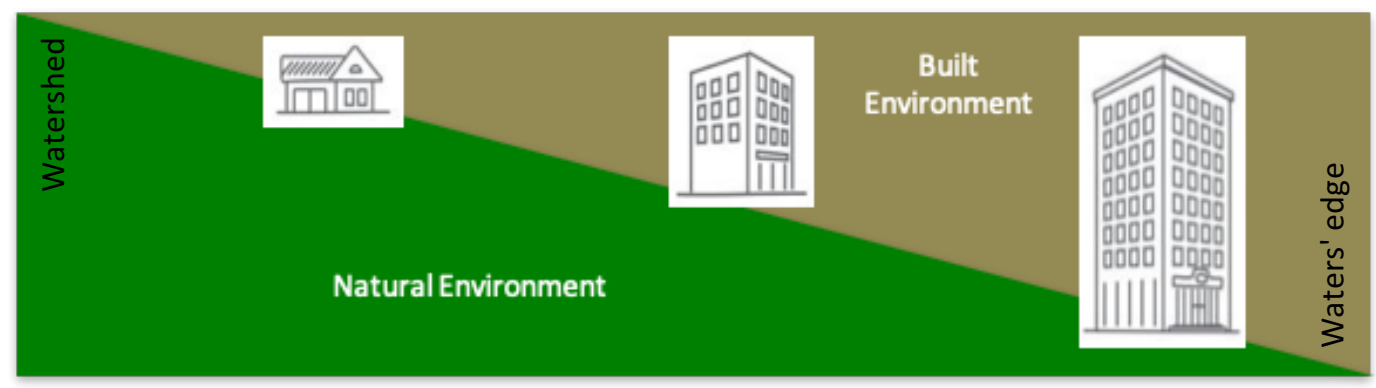

Figure 7: The natural and built environmental factors as a transect

The first step is to observe that figure 6 can also be mapped as a cartoon of a transect through an urban region, from watershed to waters' edge (figure 7), demonstrating that an understanding of the urban transect is fundamental to understanding urban sustainability. 


\subsection{Transect Planning}

Many statutory planning systems use land use as their primary organising principle and then control built form by regulations specific to particular land uses. From the town of Seaside (1981, by Andre Duany and Elizabeth Plater-Zyberk of DPZ, Miami, USA for Robert Davis) onwards the New Urbanists have instead regulated built form first and then controlled land use, as necessary, by specific regulations (Katz, 1994).

The form-based code was further developed by adapting to it transect analysis from environmental science (Centre for Applied Transect Studies, 2016). This has resulted in a very useful body of knowledge and related planning and design techniques, including many images that are available on-line, such as figure 8 below, from the latest version of The SmartCode Version 9 and Manual (Duany, Sorlein and Wright, 2008), which comprehensively details the use of transect-based plans and aligns them to the United States statutory planning system.

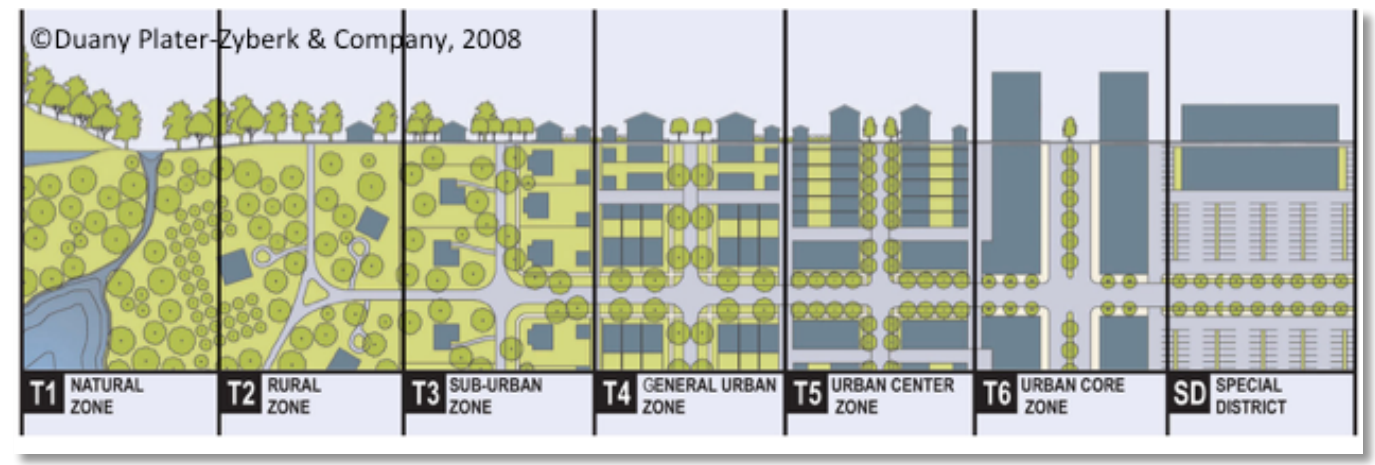

Figure 8: The current standard diagrammatic representation of the prototypical rural-tourban transect.

It is also important to appreciate that the urban ecological zones designated as T1 to T6 are usually grouped into community units before areas are designed in detail (figure 9). Essentially, the urban structure is formed from these units and their supporting infrastructure. The standard community units are usually:

- $\quad$ Clustered Land Development (CLD), e.g. a hamlet, typically contains T2, T3 \& T4;

- Traditional Neighbourhood Development (TND), e.g. a village or a neighborhood, typically contains T3, T4 \& T5;

- $\quad$ Transit Oriented Development (TOD) e.g. a neighborhood or district centre with good transit, it also typically contains T3, T4 \& T5; and

- Regional Centre Development (RCD), e.g. a regional centre or the central buisiness district (CBD), which typically contains T4, T5 \& T6 with good transit.

Notably, a Special District is neither an urban ecological zone, nor a community unit. It is a catch-all category for everything else: "Some types of uses are justified in not fitting neatly into a transect ecozone and therefore must be treated separately. First, it is necessary to include a category (or "district") for land uses that are either exceedingly large, noxious, or for some other good reason do not fit automatically into an ecozone." (Duany and Talen, 2002, p.256). (Note that in this paper 'urban ecological zone' is preferred to 'ecozone'.) 


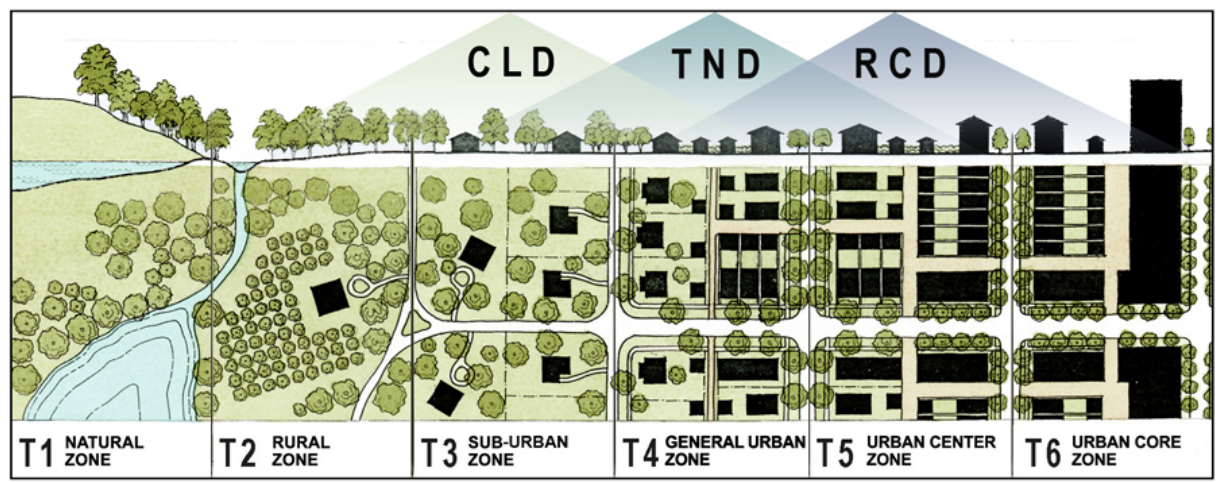

Figure 9: A variation on the transect diagram emphasising the prototypical relationship between transect elements and the community units: CLD, TND and RCD. (Sorlien, 2011)

This simple analysis clearly demonstrates that in urban planning the sustainability factors resolve into the application of a rural-to-urban transect that is already well understood, at least by leading practitioners and some academics. But is that all there is? Can every city plan be reduced to T1 to T6 plus the catch-all "Special Districts"? Clearly, as prototypical elements, T1 to T6 are almost unchallengeable, but perhaps Special Districts requires further examination.

\section{What's So Special About Special Districts?}

\subsection{Boundary Conditions}

Surveys of existing conditions and similar planning studies rarely pay attention to the boundary conditions of large areas devoted to a single purpose, but it is key to how such areas relate to the rest of the urban fabric.

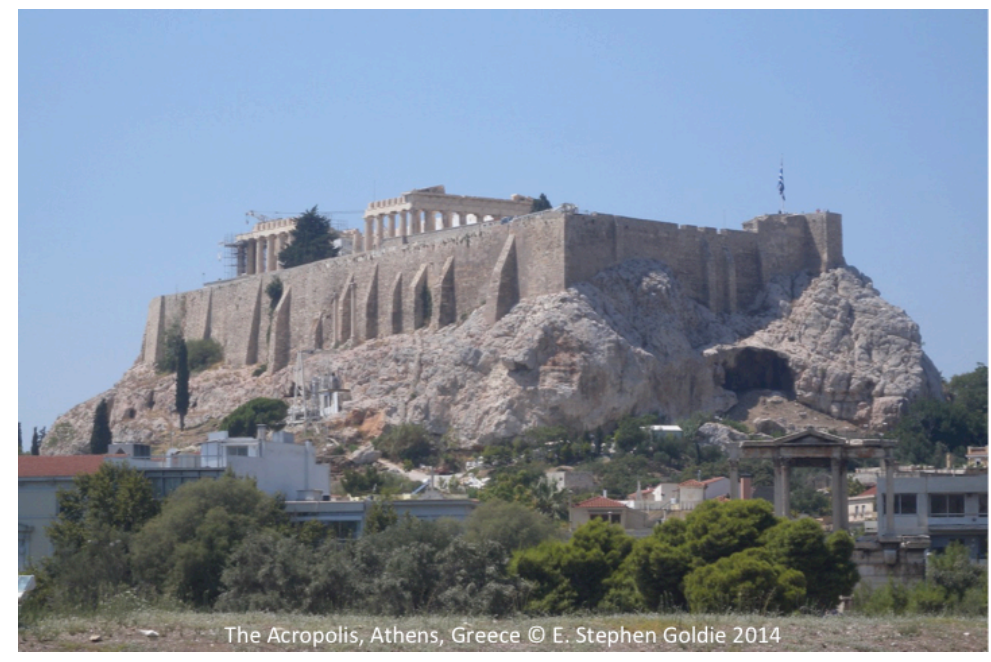

Figure 10: A fortified boundary, approx. $250 \times 150$ metres or $820^{\prime} x$ 490 ', protects the Acropolis

The Acropolis, rising majestically above the central area of Athens, Greece (figure 10) is possibly the archetype of all special districts. It is about the size of three city blocks, so it is not 
as large an element as it seems. Clearly, the defining feature is its fortified boundary, a wall designed to add to the natural defensive qualities of the hill on which it sits, while also increasing the area within which people could shelter in time of attack. Over the centuries, defenders of the Acropolis have never been defeated by direct assault, only by encirclement and the threat of starvation.

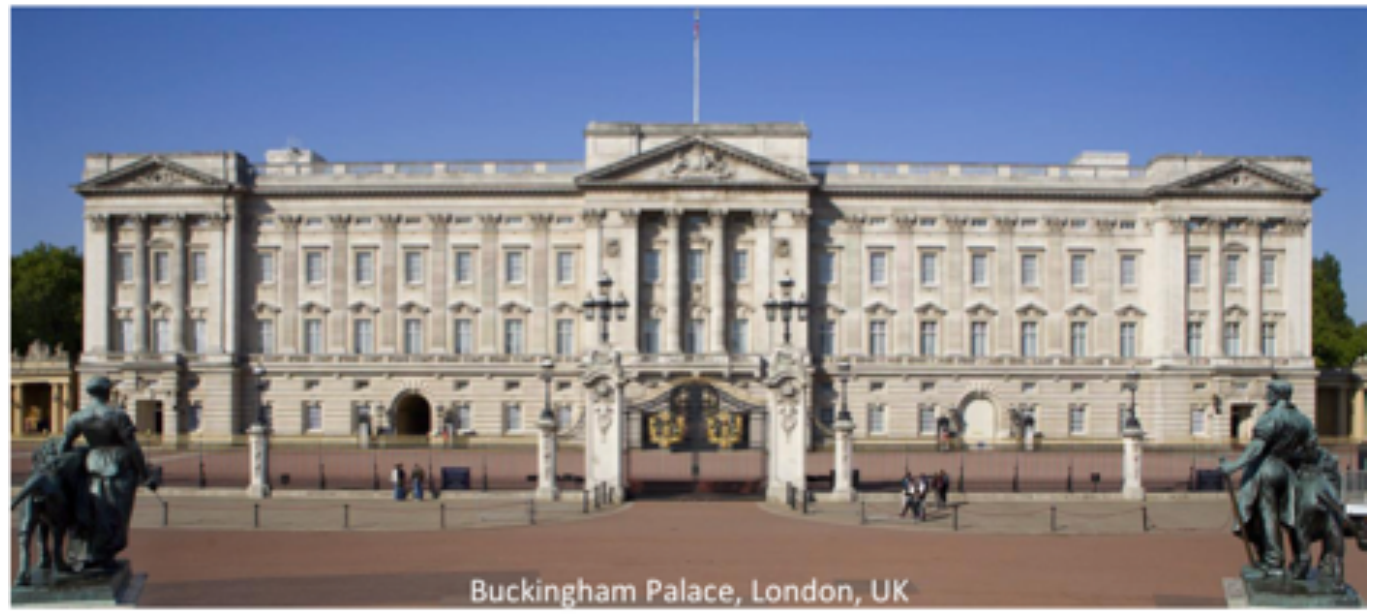

Figure 11: A secured boundary surrounds Buckingham Palace, part of an irregularly shaped complex approx. $520 \times 610$ metres or $1,700^{\prime} \times 2,000^{\prime}$

Buckingham Palace in London (figure 11) occupies a much larger area. The site is irregular in shape, but perhaps it could contain around fifteen city blocks. Unlike the Acropolis it has a secured boundary, one designed to be guarded, but not to withstand a heavily armed assault.

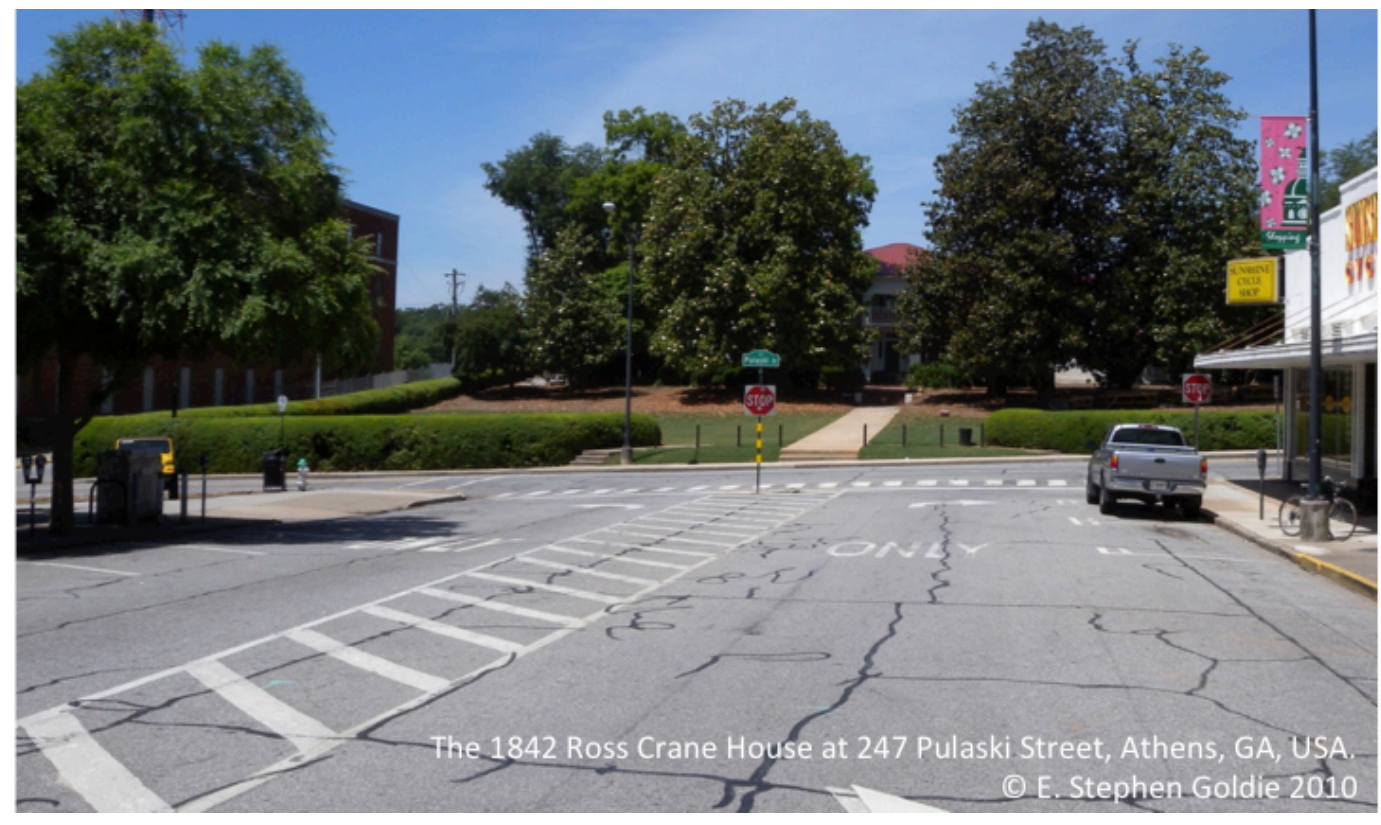

Figure 12: A fenced boundary (or in this case, a hedge) demarcating the front garden of this ¿AE Fraternity House's 420' x 200' plot (approximately $130 \times 60$ metres) 
In contrast to the two preceding examples, a fenced boundary is very common. The term 'fence' is used here to indicate a demarcated boundary, as in the magnificent hedge around the $\Sigma A E$ Fraternity House in figure 12. 'Fenced' also includes ha-has and the wide expanses of 'free-fire zone' lawn and shrubbery used to discourage unregulated pedestrian access to campus style developments, such as a business park. In this context then a "fence" is any form of physical demarcation that is more than a line on a map but less than the sort of fence or wall intended to deter a purposeful intruder.

To complete the set, we need only to add the case where the only demarcation of a boundary is by a few surveyor's pegs or marks. This gives us the simple, but very useful symbols proposed at figure 13, in which the symbols for surveyed and fenced boundaries are standard drawing practice and the symbols for secured and fortified boundaries are standard NATO map-marking practice (respectively a barbed wire fence and a trench line). Finally, when a fenced, secured or fortified boundary encloses an area greater than four hectares (ten acres) drawing these symbols in red will highlight them as potential special districts.

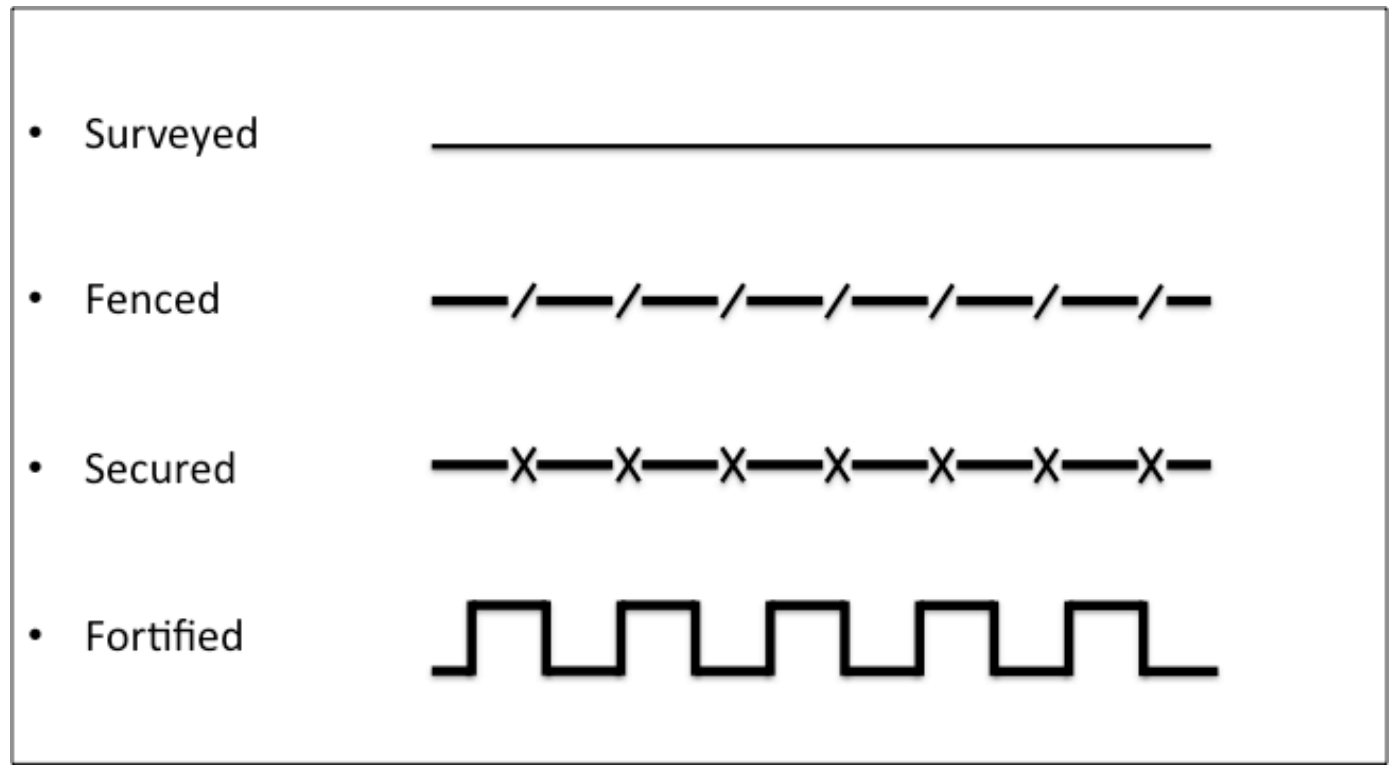

Figure 13: Graphics for boundary conditions

The key point is that physically defined (i.e. fenced, secured or fortified) boundaries constrain movement. The areas outside and inside might be walkable, but the community is prevented or discouraged from walking from one to the other. When these areas are smaller in size than a large city block (say 200 metres or 660 feet square) there is usually little impact on walkability, but when they cover even slightly larger areas than this they have a major impact on the urban fabric. Obviously, the impact is situational, but generally the larger the area enclosed, the greater the impact. This factor allows us to distinguish true special districts from the missing urban-ecological zones and to complete our understanding of the elements of urbanism. 


\subsection{The Periodic Table of Urbanism}

If the prototypical urban transect from watershed to the city centre is expanded to the water's edge, and if, within that transect any special districts, such as a jail, university, boarding school, etc. can be properly identified by a distinct boundary condition, then it is possible to arrange into one 'urban periodic table' (figure 14) the standard rural-to-urban transect extending from watershed to water's edge. This extended transect can now include all of the productive, transport and other uses in the city, the temporary and aberrant types of development, and an expanded range of community units, including special districts as now defined in the section following.

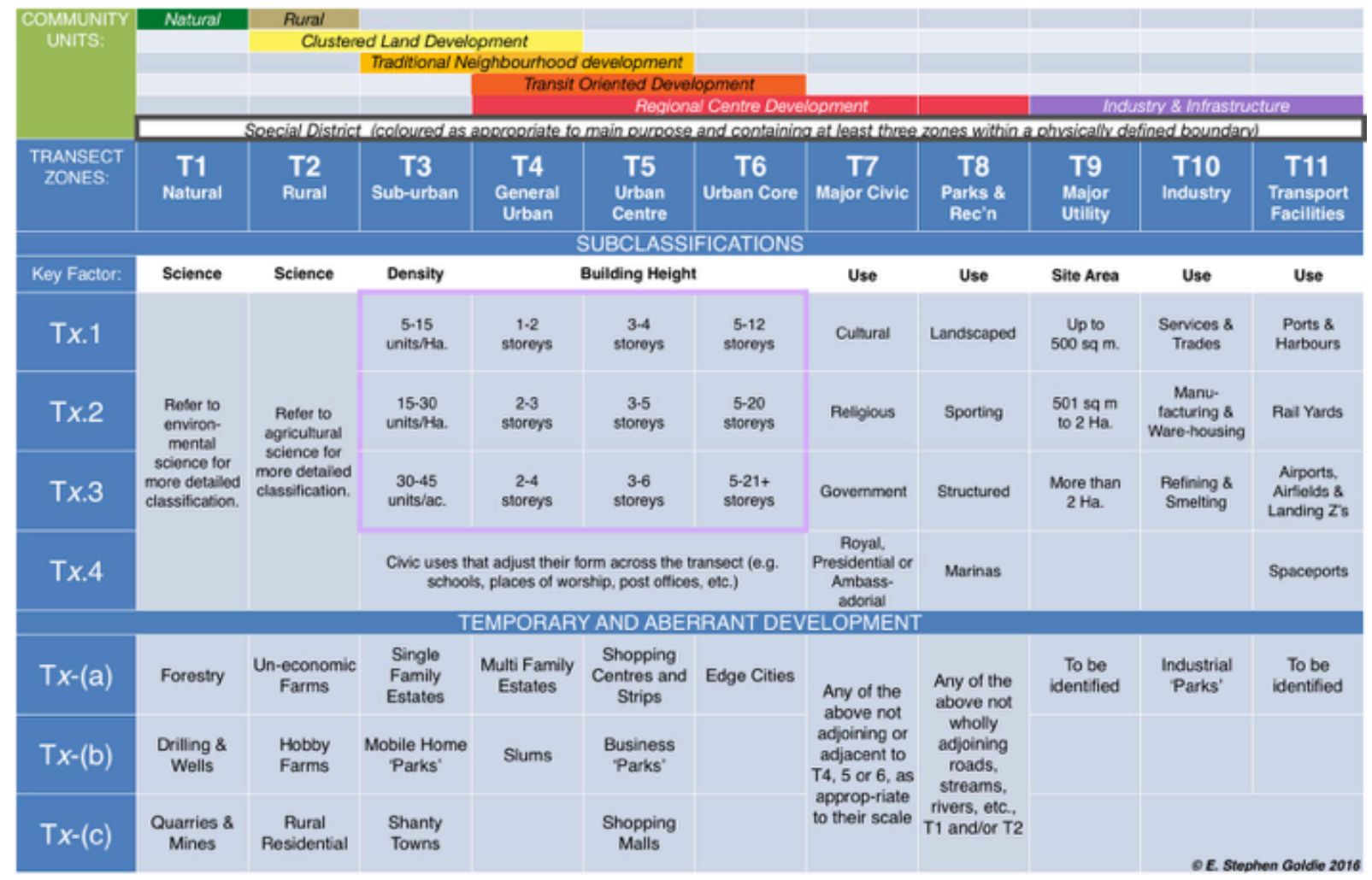

Figure 14: The Periodic Table of Urbanism

Note that within figure 14, in the left hand column, ' $x$ ' represents the relevant T-zone in the row headed 'Transect Zone', e.g. T1.1 and so on. Note also that the numerical values given for some transect zones are tentative and require ground-truthing through case studies.

The Periodic Table of the Elements is deliberately arranged to demonstrate the periodicity and grouping of the atoms. Similarly, the columns in the Periodic Table of Urbanism are all grouped by function, while the core box of twelve transect zones (outlined in lilac) demonstrate the urban equivalent of periodicity. These three rows across four columns (T3.1 to T6.3) are typical local transects identifying four distinct, but co-dependent arrangements of built form. For example, suburbs at 5 to 15 units per hectare ( 2 to 6 units per acre) are only going to support general urban development one to two storeys in height and so on. 
Studies and research to identify the mathematical relationships between each transect element, stable and unstable, are currently underway and should form the subject of a future paper.

The simultaneous complexity and simplicity of the Periodic Table of Urbanism hint at a greater order of things, too big to be considered here, but perhaps:

This is pretty remarkable evidence that there is a mysterious unity about the patterns found throughout the whole of creation. From the smallest of molecules to the biggest of planetary 'particles;' revolving around the sun, everything depends for its stability upon an incredible simple, very elegant geometric patterning - the grammar of Harmony. (HRH The Prince of Wales, Juniper and Skelly, 2010, p. 118)

Whether towns of thousands of people and cities of millions are more or less complex than the 118 chemical elements so far discovered is debatable, but as Professor Dmitri Mendeleev is quoted as saying:

It is the function of science to discover the existence of a general reign of order in nature and to find the causes governing this order. And this refers in equal measure to the relations of man - social and political - and to the entire universe as a whole. (Posin, 1948, p. 167)

Just as the Periodic Table of Chemistry identifies the physical components of our universe and is able to predict the relationships between them, the Periodic Table of Urbanism provides a comprehensive framework for describing the "general reign of order" in our towns and cities. It also enables the development of an algorithmic framework for both understanding existing urbanism and for plan making, as a necessary step towards the positive application of artificial intelligence to urban planning.

\subsection{Special Districts as a Community Unit}

As explained at section 3.2. Transect Planning, the transect zones are usually grouped into community units and the urban structure is formed from these units and their supporting infrastructure. The preceding discussion has now made it clear that the term 'special district' is not required to describe or classify the elements of urban sprawl, nor is it required to provide for the missing transect zones that have been tentatively catalogued above; however, there is a need for a term to describe special groupings of transect elements in circumstances that meet the following proposed definition (see figures 10 to 13 regarding fenced, secured and fortified boundaries). Therefore, I propose that:

\section{A Special District is a special purpose community unit containing at least three urban-ecological zones within a physically defined boundary.}

Typical examples include airports, boarding schools, citadels (a heritage feature in many European cities), colleges, convents, hospitals, military bases, monasteries and universities, and would be labelled 'special district-airport', 'special district-boarding school', etc. Along with a defined boundary, these urban elements will also have an internal transect structure, as the examples at figure 15 notionally demonstrate. They are almost cities within cities. 


\begin{tabular}{|l|l|}
\hline Special District - Jail/Gaol & Special District - Barracks/Fort \\
\hline Secured boundary $(-x-x-)$ & Secured boundary $(-x-x-)$ \\
\hline T5 Administration, classrooms and theatres & T3 Married quarters \\
\hline T5 Cell blocks & T4 Town centre \\
\hline T8 Sports fields & T5 Bachelor quarters \& barracks \\
\hline T10 Workshops \& stores & T5 Administration, classrooms and theatres \\
\hline & T10 Workshops \& stores \\
\hline & T8 Sports fields \& firing ranges \\
\hline Special District - University Campus & T1 Close training area \\
\hline Fenced* boundary (-/-/-) & Special District - Hospital Complex \\
\hline T5 Dormitories & Fenced boundary (-/-/-) \\
\hline T5 Theatres, lecture halls \& seminar rooms & T4 Specialist treatment \& support facilities \\
\hline T6 Administration \& libraries & T6 Wards, theatres and administration \\
\hline T8 Gardens \& sports fields & T8 Gardens \\
\hline T10 Laboratories, workshops \& stores & T10 Workshops \& stores \\
\hline & T9 Incinerator \\
\hline * 'fenced' means anything intended to demarcate private land, but to a lesser degree than 'secured' or 'fortified'. \\
\hline
\end{tabular}

Figure 15: Likely transect zones across some typical special districts

Returning to the three examples of boundary conditions given above, the Acropolis (figure 10) can now be classified, in accordance with the Periodic Table of Urbanism at figure 14, as a Special District-Heritage with a fortified boundary and mostly containing the transect zone T7.1 Cultural; Buckingham Palace (figure 11) as Special District-Palace with a secured boundary and dominated by the transect zone T7.4 Royal; while the $\Sigma A E$ Fraternity House (figure 12) is not a special district, just a very nice element within a T4 urban ecological zone.

So, the answer to the question posed earlier "can every city plan be reduced to T1 to T6 plus Special Districts?" is no, but every city plan can be reduced to T1 to T11, with up to seven subclassifications, a grid of up to seventy-seven urban ecological zones. As proposed at figure 14 above, the grid currently contains fifty-four defined urban ecological zones, but no doubt some of the blanks will be filled in after practical experience of its application.

It should be clear to all planners and urban geographers that a rural-to-urban transect comprised of the urban ecological zones proposed in the Periodic Table of Urbanism can be mapped across all urban areas. Transect based plans are a subset of form based codes and:

As of June 2019, we've tracked 728 codes [in the United States and Canada] that meet criteria established by the Form-Based Codes Institute ( $F B C I)$, as well as an additional 17 form-based guidelines. 439 of these are adopted, with others in progress. Even though form-based codes are 38 years old, $91 \%$ have been adopted since 2001 (Borys, Talen and Lambert, 2019).

So, transect planning has utility as a planning tool, but can it be used in conjunction with some form of artificial intelligence to predictably guide the preparation of plans in at least a partially automated process? 


\section{Smart Planning for Smart Cities}

\subsection{Artificial Intelligence Supported Planning}

Professor Michael Batty is the Bartlett Professor of Planning at University College London where he is Chair of the Centre for Advanced Spatial Analysis and is a leading researcher in this field. Over two decades ago he wrote that:

Computer models of cities either attempt to simulate existing urban form or provide procedures for the design of optimal forms, but rarely both. The mechanisms used to model actual cities usually embody local behavioural descriptions without explicit optimizing,' whereas those that produce idealized forms seek to optimize in a more global fashion, often mirroring the viewpoint of the designer. (Batty, 1997)

More recently he published The New Science of Cities (Batty, 2013) in which he demonstrates a mathematical system where all actors (community, planner and politician) are replaced by algorithms. However, as in all situations involving the application of untested new technologies, it is appropriate to try many different approaches. Sometimes one or the other becomes the preferred standard, but more often than not each new approach encourages improvements in the others, leading to a convergence towards efficiency and effectiveness.

With this in mind, the approach that I propose aims to simultaneously "simulate existing urban form [and] provide procedures for the design of optimal forms", by mapping at the regional scale the following factors:

- Topography (shown by the thick white line in figure 16);

- Travel time to centre (shown as "ta" for travel time by automobile, "tb" for bus and "tt" for train in figure 16);

- Locational rent, in accordance with the work of Johann Heinrich von Thünen (17831850) who developed locational rent as a mathematically rigorous theory of marginal productivity (shown as "vr" for value of retail rents, "vm" for manufacturing rents and "vh" for housing rents in figure 16), (Wikipedia, 216a); and

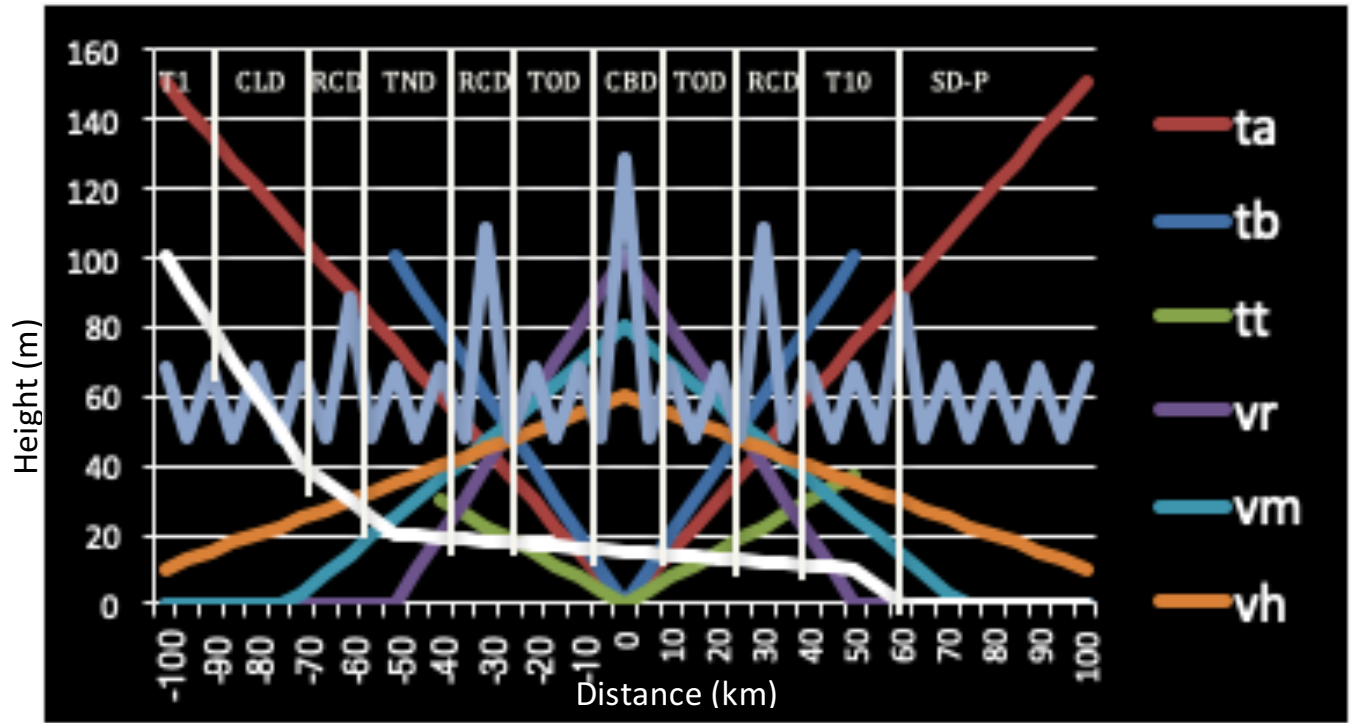

Figure 16: Analysis of urban structure by multiple factors along a theoretical transect. 
- Total retail and commercial floor space, in accordance with Central Place Theory as proposed and utilised by the German geographer Walter Christaller (1893-1969), (shown as the light blue line in figure 16), (Wikipedia, 216b).

When these factors are combined into one graph (fig. 16) the results look slightly confusing (even in this fictional example) but when the transect-based planning community units are applied the urban structure is immediately clear: from left to right T1 (i.e. natural), then CLD (e.g. a hamlet), RCD (e.g. a small town on the edge of the urban area), TND (e.g. traditional fine-grained, mixed-use, walkable neighbourhoods), TOD (transit oriented development), CBD (central business district) and so on through to SD-P (e.g. a special district containing a port) on the coast.

Inclusion of additional operational theories of planning, such as the Chicago School models and Reticular Matrix (Ortiz, 2014) improves the reliability of the analysis, but for the purposes of this paper figure 16 is sufficient.

By repeating this exercise with parallel transects across the area to be planned, suitably designed prediction machines (Agrawal, Gans and Goldfarb, 2018) will produce an outline structure plan, as notionally illustrated at figure 17.

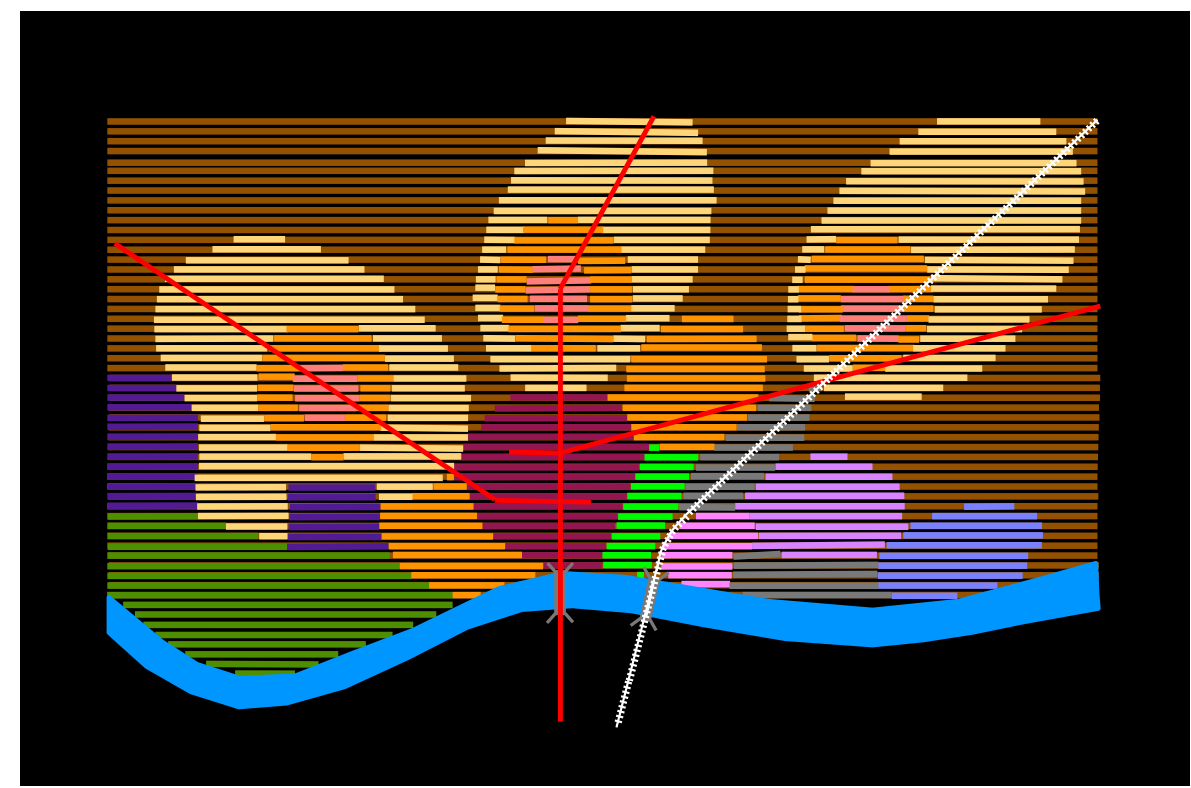

Figure 17: Illustration of how a first draft of a structure plan map might look when developed by an artificial intelligence analysing optimum urban structure along multiple parallel transects.

Applying this analysis to any urban area where the natural areas that are to be retained have been identified, and a transect-based synoptic survey and localising process has been completed, should very quickly produce a 'first-draft' urban structure plan. Refining this plan, checking infrastructure and traffic demand, etc. should follow expeditiously, because it is usually the process of preparing and testing the 'first-draft' many times that is the most timeconsuming element. Note that the process of designing the community units in detail is still a professional design process, but this can be done in stages, as required, after the urban structure has been resolved and while the major infrastructure design is underway. 
So, it has been demonstrated, using a hypothetical example, that standard urban metrics, applied using well understood theories can be combined with transect-based planning to automate the production of a 'first-draft' urban structure plan. With collective experience this process will become more rigorous and more reliable, producing the first draft of a metropolitan structure plan in hours instead of months and also vastly simplifying scenario testing

However, at the same time that the digital revolution is likely to accelerate urban planning processes, it is also likely to change at least one of the fundamentals of the city: employment. If there are no jobs, will cities cease to exist?

\section{The Jobless City - Revolution or Paradise}

It is highly likely that over the next two decades there will be a massive loss of industrial and service jobs in the western world, of the order of 80\%, (Furman et al, 2016; CEDA, 2015) at exactly the same time as the mechanisation of agriculture in the global south is driving rapid, massive $3^{\text {rd }}$ World urbanisation. Issues that humanity must deal with while also preventing nuclear war and avoiding biological annihilation.

Vivek Wadha, writing in the Washington Post ${ }^{30}$ (Wadha, 2015) said that "We need a new version of capitalism for the jobless future". Perhaps a revival of co-operative ownership could be part of that model, an economy where:

- The citizens own the city;

- The city consists of all of the usual land uses (residential, schools, hospitals, etc.) renting these out, or operating them itself, as the citizens decide;

- The city owns the land of production (mining, agricultural and industrial);

- The city receives rents from the business owners or in-kind food and products;

- The city maintains itself and provides for the needs of its citizens in the form of food and clothing rations, access to education, health, recreation, entertainment, etc.; and

- The city distributes any surplus income to the citizens as a dividend and/or special purpose grants.

The Digital Revolution increases profits by decreasing labour, but there is no evidence yet that it decreases floor space. What will decrease is the need for worker transport, including parking. Therefore, robotised industrial land requirements might decrease by around $50 \%$ as parking areas are turned to more productive uses, but the roads and railways will probably be retained for the movement of raw materials and finished product. As the volume of production rises the value of the land rises and therefore rents can rise. There is no reason why a modern version of Ebenezer Howard's co-operatives could not capture that value (Howard, 1965, p. 58). Equally, urban and indoor agriculture reduces the agricultural hinterland required, thereby reducing land costs for a new city, and transport costs in bringing that produce to town. Areas of saving that could also be captured by a well-planned cooperative.

As explained earlier, "An additional 3 billion urban residents in forty years translates into a need to build a new city for a population of one million people, complete with hospitals, schools, workplaces, recreation and all the rest, at a rate of more than six a month" and clearly, 
building one new city of any form will have no impact on a problem of this magnitude. So, perhaps multiple experimental cities are required on each continent, the successes being quickly replicated (in type, not in exact design, which should always be bespoke) and then replicated again, increasing exponentially, until all of humanity that wishes to live in cities can do so in to a satisfactory standard.

So, what are the options: scattered, idyllic rural villages, dense European urbanism or so far untested sci-fi archologies? Letchworth (population 35,000) near London, indicates that while the land ownership model may be relevant, the size is probably much too small, so that probably excludes idyllic rural village as an option, leaving archology, dense European city, or something in-between.

I have previously shown (Goldie, 2017) that both traditional European urbanism or a city-in-abuilding archology could provide the physical models for the jobless cities that we should have started to build yesterday. Which of these will work best is likely to be determined by the degree to which each city's planning and design minimises environmental impact, maximises sustainability and, most critically, supports a functioning economic model that will "meet our needs as defined by the bottom two layers of Maslow's hierarchy of needs (physiological and safety) ... thereby unleashing the next wave of human innovation and creativity in directions we can never imagine." (CEDA, 2015, p. 46)

\section{Global Responses}

There have been numerous high-level international meetings, forums and conferences at which the problem of rapid, massive, third-world urbanisation (RAMTU) is notionally addressed by goals, objectives and performance indicators (GOPI). These include the State of the Planet Declaration, the World Urban Forum, Habitat, the New Urban Agenda and the United Nation's sustainable development goals, as outlined below.

\subsection{2 - The State of The Planet Declaration}

The Planet Under Pressure: New Knowledge Towards Solutions conference (London, 26-29 March 2012) "... brought together nearly 3000 leading experts and decision-makers to discuss global challenges and offer new solutions." an additional 3000 people participated on-line. The first point in the State of the Planet Declaration is:

Research now demonstrates that the continued functioning of the Earth system, as it has supported the well-being of human civilization in recent centuries, is at risk. Without urgent action, we could face threats to water, food, biodiversity and other critical resources: these threats risk intensifying economic, ecological and social crises, creating the potential for a humanitarian emergency on a global scale. (Brito and Smith, 2012, p. 1)

Unfortunately, the only actions proposed were to "fund and support capacity building in science and education globally ..." and related actions (Brito and Smith, 2012, p. 3).

\subsection{1 - World Urban Forum}

The World Urban Forum (WUF) is the world's premier conference on urban issues. It was established in 2001 by the United Nations to examine one of the most pressing issues facing 
the world today: rapid urbanization and its impact on communities, cities, economies, climate change and policies.

Organized and convened by UN-Habitat, the Forum has become one of the most open gatherings on the international arena, for exchanging views and experiences on urban challenges. The inclusive nature of the Forum, combined with high-level participation, makes it a unique United Nations conference and the premier international gathering on urban issues.

The World Urban Forum has the following objectives:

- raise awareness of sustainable urbanization among stakeholders and constituencies, including the general public;

- improve the collective knowledge of sustainable urban development through inclusive open debates, sharing of lessons learned and the exchange of best practices and good policies; and

- increase coordination and cooperation between different stakeholders and constituencies for the advancement and implementation of sustainable urbanization.

The Ninth session of the World Urban Forum (WUF9), was held in Kuala Lumpur, Malaysia in February 2018, and has been recognized by the United Nations General Assembly (resolution 70/210) as the first session to have a thematic focus on the implementation of the New Urban Agenda adopted at the United Nations Conference on Housing and Sustainable Urban Development, Habitat III.

The Tenth session of the World Urban Forum (WUF10) will take place in Abu Dhabi, United Arab Emirates in 2020. It will be the first Forum to be held in the Arab region and it will be another opportunity to review the implementation of the New Urban Agenda.

\subsection{5 - Sustainable Development Goals}

The Sustainable Development Goals (SDGs) are a collection of 17 global goals set by the United Nations. The broad goals are interrelated, though each has its own targets to achieve. The total number of targets is 169 . The SDGs cover a broad range of social and economic development issues. These include poverty, hunger, health, education, climate change, gender equality, water, sanitation, energy, environment and social justice. The SDGs are also known as "Transforming our World: the 2030 Agenda for Sustainable Development" or Agenda 2030 in short. The goals were developed to replace the Millennium Development Goals (MDGs) which ended in 2015. Unlike the MDGs, the SDG framework does not distinguish between "developed" and "developing" nations. Instead, the goals apply to all countries.

Paragraph 54 of United Nations Resolution A/RES/70/1 of 25 September 2015 contains the goals and targets. The UN-led process involved its 193 Member States and global civil society. The resolution is a broad intergovernmental agreement that acts as the Post-2015 Development Agenda.

The SDGs build on the principles agreed upon in Resolution A/RES/66/288, entitled "The Future We Want". This was a non-binding document released as a result of Rio+20 Conference held in 2012. (United Nations, 1992, resolution 1, annex I)

The goal most relevant to this discussion is Goal 11: Sustainable Cities \& Communities:

Make cities and human settlements inclusive, safe, resilient and sustainable. 


\subsection{6 - Habitat III and the New Urban Agenda}

The United Nations Conference on Housing and Sustainable Urban Development, known as Habitat III, concluded on 21 October 2016 in Quito, Ecuador, with delegations adopting the New Urban Agenda - a new framework that that lays out how cities should be planned and managed to best promote sustainable urbanization.

"We have analyzed and discussed the challenges that our cities are facing and have [agreed] on a common roadmap for the 20 years to come," Joan Clos, Secretary-General of the conference and Executive Director of the UN Human Settlements Programme (UN-Habitat), told participants at the closing session. (UN News 2016)

The conference in Quito, lasted one week and drew around 36,000 people from 167 different countries, with a reported 50,000 also visiting the various associated exhibition areas.

Clos said that the document should be seen as an extension of the 2030 Agenda for Sustainable Development, agreed by 193 Member States of the UN in September 2015 (UN News 2016).

The Agenda for Sustainable Development's 17 Sustainable Development Goals (SDGs) recognized the power of cities and towns, which will constitute up to 70 per cent of the world population by 2050, to be the engine for sustainable growth in the future. The New Urban Agenda gives greater emphasis to this concept.

Implementation is covered by paragraphs 23 to 175 of The New Urban Agenda. (United Nations, 2017) Almost every paragraph starts with "We will ...", "We commit to ...", and so on. These statements include:

- $\quad$ 102. We will strive to improve capacity for urban planning and design and the provision of training for urban planners at national, subnational and local levels.",

- $\quad$ "109. We will consider increased allocations of financial and human resources, as appropriate, for the upgrading and, to the extent possible, prevention of slums and informal settlements, with strategies that go beyond physical and environmental improvements to ensure that slums and informal settlements are integrated into the social, economic, cultural and political dimensions of cities."; and

- $\quad$ "126. We recognize that the implementation of the New Urban Agenda requires an enabling environment and a wide range of means of implementation, including access to science, technology and innovation and enhanced knowledge-sharing on mutually agreed terms, as well as capacity development and mobilization of financial resources, taking into account the commitment of developed and developing countries and tapping into all available traditional and innovative sources at the global, regional, national, subnational and local levels, as well as enhanced international cooperation and partnerships among Governments at all levels, the private sector, civil society, the United Nations system and other actors, based on the principles of equality, non-discrimination, accountability, respect for human rights and solidarity, especially for those who are the poorest and most vulnerable." 
In response to these points, or for other compelling reasons, there are programs designed to address such issues, for example:

From the Federal government's point of view, it is indeed essential to tackle the root causes for irregular migration. This includes improving living conditions and creating better perspectives in countries of origin, notably in Africa. The Federal government has already been very active in this field. This includes projects in education, vocational training, job creation, health, infrastructure or food security, to mention only a few. In the year of 2017, the German government has spent a total of 6.6 billion EUR to this end alone. (Helmert, 2018)

The question is whether billions of Euros, dollars or dirhams directed piecemeal to education, vocational training, job creation, health, infrastructure, food security, etc. are sufficient to make a difference, or whether it would be better to direct all efforts to the one endeavour that is likely to provide a permanent solution: city building.

As the Germans say, stadtluft macht frei (the city makes you free).

\subsection{Conclusions Regarding International Responses}

While the goals, objectives and performance indicators developed and adopted at these various global meetings, forums and conferences are most worthy, it is notable that while there are many "we will's" there is no mention of 'how' or 'with'. Wars might happen by accident, but great cities do not. Even if they did, such good fortune is very unlikely in the great arc of growth stretching from West Africa through the Middle East, across Asia and into the Pacific, and most certainly not two thousand times in the next thirty years.

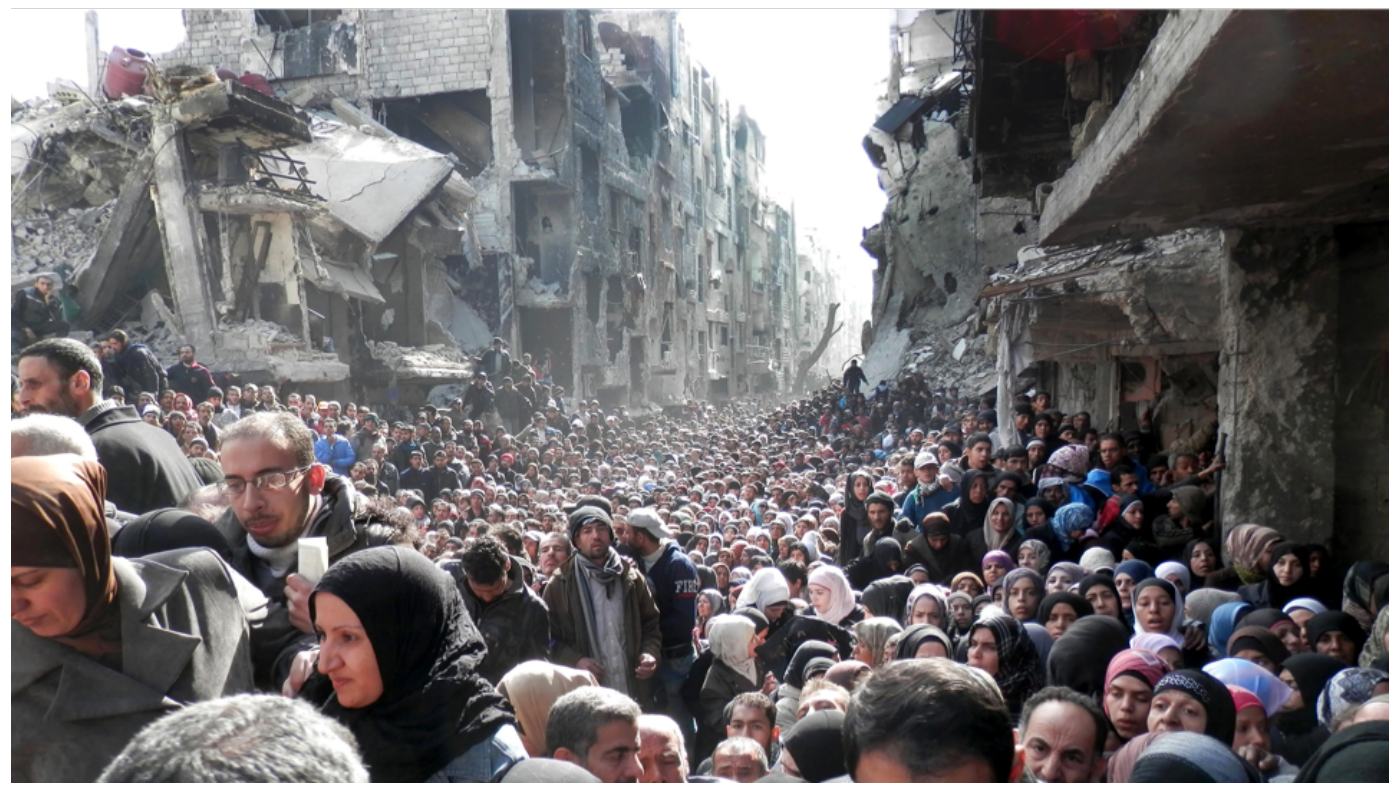

Figure 18: Residents line up to receive food in the besieged Palestinian camp of Yarmouk, Damascus, Syria 31 Jan 2014. CAP/UNRWA

Notably, the most senior public official on the planet has warned that everything that humanity has done so far to address this challenge is not enough: 
The UN Secretary-General has told a major climate change conference that the world faces a battle for its survival.

António Guterres said despite the existential threat, not everyone was confronting the problem with due focus.

Speaking in Abu Dhabi on Sunday, Mr Guterres also made an impassioned call for greater support to help develop the green economy.

"The world is facing a grave climate emergency - disruption is happening now and faster than top scientists predict," he said.

"Every week brings more devastation, floods, drought and...superstorms. All around the world, people are losing their homes and forced to migrate.

"The situation only gets worse and we must act now with urgency. We have no time to lose." (Dennehy, 2019)

Obviously, Franklin's Law is as true today as when the great man first coined it: "If the poor folks are happier at home than they can be abroad, they will not be lightly prevailed with to cross the ocean." (Benjamin Franklin, 1706-1790, from Zolberg, 2006, p. 46), So, not only are the goals discussed above sensible, they are based in long understood common sense, but the questions remain: how, when and where will these goals, objectives and performance indicators actually be implemented in sufficient scale to make a difference? How do we plan and build enough cities, or city expansions, well enough and quickly enough to solve a threebillion-person problem?

\section{How to Plan and Build 2000 New, Million-Person Cities by 2050}

\subsection{Physical Resources - The Planning Staff}

Whatever the technologies used to support the planning process they will not (at least not for a generation or two) replace the need for trained urban planners and designers.

At the local government level, such as the planning of a new town or city, the resources applied to planning depend upon many local factors, not least of which are the relevant laws and regulations of the state, but in my experience most of these factors can be subsumed into one constant, the size of community that one local government planer can manage if it is growing at $1 \%$ a year. Let us call this population the single planner population (SPP). For example, assume that this factor is constant within any particular state (i.e. emirate, province, nation, state, etc.), then the number of planning staff (S) will be given by the population (P) and the rate of growth, actual or desired, whichever is the greater, $(\mathrm{R} \%)$ as follows:

$$
S=\frac{P \times R}{S P P}
$$

Finding the value of the single planner population (SPP) for any jurisdiction is simply a matter of auditing all planning organisations in that jurisdiction and taking the average (of course the audit has to normalise for consultant budgets and professional-to-support staff ratios in order to ensure an accurate comparison). As always there will be special cases and varying preferences for in-house teams over consultants, but in my experience this simple formula gives remarkably consistent results. 
So if there is a town of 12,500 people growing at $1 \%$, and the SPP for that state is 12,500 then the number of local government planners required to manage the plan making, plan implementation and administration for that town effectively and efficiently is one, because:

$$
\begin{aligned}
& S=\frac{12,500 \times 1}{12,500} \\
& S=1
\end{aligned}
$$

Scaling this up to a city of $1,000,000$ growing at $1.5 \%$, we get a staff requirement of one hundred and twenty, as follows:

$$
\begin{aligned}
& S=(1,000,000 \times 1.5) / 12,500 \\
& S=120
\end{aligned}
$$

Clearly, the same city, growing at twice the rate requires twice the staff, because:

$$
\begin{aligned}
& S=(1,000,000 \times 3.0) / 12,500 \\
& S=240
\end{aligned}
$$

Cities exist because they give economies of scale, but unfortunately, budget makers rarely recognise that in town planning increased size and/or rate of growth creates more problems, not fewer, because human interactions increase exponentially. The fact that this equation increases staff requirements geometrically, not exponentially, demonstrates that there are economies of scale in the planning of a city, but usually not to the degree desired by budget makers.

These same budget makers might also express a tendency to assume that technologies such as automated approvals will allow a reduction in staff. However, if this is done I am confident that the "garbage in, garbage out" rule will quickly assert itself and more planners, rather than fewer, will be required to sort out a mess that we do not have the time to deal with. It would be much more prudent to redeploy statutory planners to planning and urban design, or provide additional training in order to employ them as urban planning technologists, in order to ensure that the plans that are being converted into computer algorithms are sound, and that the outputs are audited for consistency with those plans.

If there is a short-term spare capacity in planning staff, then it would be wise for an agency (or group of agencies) to send them to undertake projects in less privileged jurisdictions. Revising Franklins Law slightly: "If poor people are able to move to nice towns and cities in their own countries, they will not be likely to seek refuge in ours." But, how many should they send? First, we require a likely rate of growth and initial population.

Given a proposed city of one million persons and assuming a density objective of 6,670 p/sq. km (e.g. Wikipedia, 2019 lists San Francisco at 6,226.3 p/sq. km in 2010), an average radius of $6.9 \mathrm{~km}$ giving an area of 150 square kilometres (sq. $\mathrm{km}$ ) and an initial average density of 1 person/sq. km. Then, applying the standard formula for compound interest with $A=1,000,000$ $P=150$, and $n=30$ years, the rate of growth $(r)$ is calculated as follows:

$$
\begin{aligned}
& r=n\left[(A / P)^{1 / n}-1\right] \\
& r=30\left[(1,000,000 / 150)^{1 / 30}-1\right] \\
& r=30\left[6,666.7^{0.0333}-1\right] \\
& r=30[1.3411-1] \\
& r=10.23 \quad \therefore R=1023 \%
\end{aligned}
$$


Applying this growth rate to the staffing problem, and assuming an SPP of 12,500 , gives:

$$
\begin{aligned}
& S=(P \times R) / S P P \\
& S=(150 \times 1023) / 12,500 \\
& S=153,450 / 12,500 \\
& S=12.276
\end{aligned}
$$

Therefore, an initial planning team of 12 full-time equivalent (FTE) urban planners, designers, other specialists (e.g. environmental scientists, urban geographers, surveyors, demographers, transport planners, planning engineers, social planners, planning technologists, etc.) and support staff (geographic information system operators, computer aided design (CAD) operators and administrative personnel) should be sufficient, on average, to produce a master plan for a city, or urban extension, of one million persons in three years. This calculation should be part of the annual budgeting process, because the staffing need will change as the city grows.

Twelve might seem to be a small number for a master plan for the equivalent of a city of one million people, but, counterintuitively perhaps, master planning a new city from scratch requires a smaller team than that required for the physical change management of an existing city with its myriad of issues, conflicts and individual applications for various consents.

In addition to confirming the site selection and preparing the master plan, this team will also be responsible for training the local team to implement the plan. Assuming that the local team have the relevant qualifications, then this should mostly be by on the job training (OJT), so they will be an additional resource, rather than a distraction from the main task.

Of course, the above assumes that the effective application of artificial intelligence to urban planning will not be available for some years, but every effort should be made to advance it, whether in the form described above, or by better approaches, because the task is very big

\begin{tabular}{|c|c|c|c|}
\hline Year & $\begin{array}{l}\text { Urban population } \\
\qquad\left(\times 10^{9}\right)\end{array}$ & $\begin{array}{l}\text { Total Population } \\
\qquad\left(\times 10^{9}\right)\end{array}$ & $\%$ \\
\hline 1950 & 0.75 & 2.50 & $30 \%$ \\
\hline 2009 & 3.42 & 6.80 & $50 \%$ \\
\hline 2050 & 6.40 & 9.60 & $67 \%$ \\
\hline Increase $2009-2050=$ & 2.98 & 2.80 & $106 \%$ \\
\hline
\end{tabular}
and humanity needs to marshal to the task every resource available.

\subsection{The Size of the Task}

The next step is to confirm the size of the task

Figure 19: Urban Population 1950-2050 (from figure 1 above).

Figure 19 shows the total population increase for all of humanity. Excluding the one billion additional urban population forecast for China, India and Nigeria leaves 1.98 B people to be housed in new urban settlements. If these new settlements are assumed to be, on average, cities, or city extensions of $1,000,000$ then the demand is for 1,980 new one-million-person cities, or equivalent urban expansions. If a $1 \%$ failure rate is allowed for (i.e. 19.8 projects) then this target can be rounded to 2,000 . 


\begin{tabular}{|c|c|c|c|c|c|}
\hline Year & Growth Factor & $\begin{array}{l}\text { Commencements } \\
\text { During the Year }\end{array}$ & $\begin{array}{l}\text { Total Number of MP } \\
\text { Commenced }\end{array}$ & $\begin{array}{l}\text { Total Number of MP } \\
\text { Completed }\end{array}$ & $\begin{array}{l}\% \text { of } \\
\text { Target }\end{array}$ \\
\hline 2020 & & 7 & 7 & 0 & $0 \%$ \\
\hline 2021 & 2 & 14 & 21 & 0 & $0 \%$ \\
\hline 2022 & 2 & 28 & 49 & 0 & $0 \%$ \\
\hline 2023 & 4 & 28 & 77 & 7 & $0 \%$ \\
\hline 2024 & 4 & 56 & 133 & 21 & $1 \%$ \\
\hline 2025 & 4 & 112 & 245 & 49 & $2 \%$ \\
\hline 2026 & 4 & 112 & 357 & 77 & $4 \%$ \\
\hline 2027 & 4 & 224 & 581 & 133 & $7 \%$ \\
\hline 2028 & 4 & 448 & 1029 & 245 & $12 \%$ \\
\hline 2029 & 4 & 448 & 1477 & 357 & $18 \%$ \\
\hline 2030 & 4 & 523 & 2000 & 581 & $29 \%$ \\
\hline 2031 & & & & 1029 & $52 \%$ \\
\hline 2032 & & & & 1477 & $75 \%$ \\
\hline 2033 & & & & 2000 & $101 \%$ \\
\hline
\end{tabular}

Figure 20: Masterplans required by year

Figure 20 shows that if we assume that, on average, each master plan can be completed within three years, and set up a program to commence seven masterplans in 2020 and grow the number of masterplan commencements by doubling the number of teams in the first two years and quadrupling them annually after that then, 2000 masterplans can be completed by 2033. Assuming twenty years for design and construction then 2000 new cities by 2053 is achievable. If new technologies and lessons learned on the first cities can be applied to speed up the process in later cities then possibly the whole task can be achieved by 2050, or earlier. So, the task is enormous, but feasible. The next question is cost.

\subsection{The Cost of Planners and Plans}

To estimate the cost, first of planning and then of design and construction of the infrastructure and key buildings, it is assumed that a level of commercial investment, owner-building or citizen labour will provide the majority of the lesser buildings.

As demonstrated at section 8.1 above, a planning team of twelve full-time equivalent (FTE) staff members at any one time should be capable, on average, of site selection and masterplan preparation for a new city for one million people within three years.

\begin{tabular}{|c|c|c|c|c|c|c|c|c|}
\hline $\begin{array}{l}\text { No of MP in } \\
\text { progress }\end{array}$ & FTE per Team & Head Office & Total FTE & Wages Growth & $\begin{array}{l}\text { Average Cost } \\
\text { per FTE per } \\
\text { Year }\end{array}$ & $\begin{array}{c}\text { Total Salary } \\
\text { Cost } \\
\left(\$ \times 10^{6}\right)\end{array}$ & $\begin{array}{c}\text { On costs, } \\
\text { operating } \\
\text { expenses etc. }\end{array}$ & $\begin{array}{c}\text { Total Cost per } \\
\text { Year } \\
\left(\$ \times 10^{6}\right)\end{array}$ \\
\hline 7 & 12 & 13 & 97 & $1 \%$ & $\$ 100,000$ & 10 & $100 \%$ & 19 \\
\hline 21 & 12 & 13 & 265 & $1 \%$ & $\$ 101,000$ & 27 & $100 \%$ & 54 \\
\hline 49 & 12 & 13 & 601 & $1 \%$ & $\$ 102,010$ & 61 & $100 \%$ & 123 \\
\hline 70 & 12 & 14 & 854 & $1 \%$ & $\$ 103,030$ & 88 & $100 \%$ & 176 \\
\hline 112 & 12 & 15 & 1,359 & $1 \%$ & $\$ 104,060$ & 141 & $100 \%$ & 283 \\
\hline 196 & 12 & 16 & 2,368 & $1 \%$ & $\$ 105,101$ & 249 & $100 \%$ & 498 \\
\hline 280 & 12 & 18 & 3,378 & $1 \%$ & $\$ 106,152$ & 359 & $100 \%$ & 717 \\
\hline 448 & 12 & 21 & 5,397 & $1 \%$ & $\$ 107,214$ & 579 & $100 \%$ & 1,157 \\
\hline 784 & 12 & 28 & 9,436 & $1 \%$ & $\$ 108,286$ & 1,022 & $100 \%$ & 2,044 \\
\hline 1120 & 12 & 35 & 13,475 & $1 \%$ & $\$ 109,369$ & 1,474 & $100 \%$ & 2,947 \\
\hline 1419 & 12 & 41 & 17,069 & $1 \%$ & $\$ 110,462$ & 1,885 & $100 \%$ & 3,771 \\
\hline 971 & 12 & 32 & 11,684 & $1 \%$ & $\$ 111,567$ & 1,304 & $100 \%$ & 2,607 \\
\hline 523 & 12 & 23 & 6,299 & $1 \%$ & $\$ 112,683$ & 710 & $100 \%$ & 1,420 \\
\hline & & & & & & & Total Cost & 15,815 \\
\hline & & & & & & \multicolumn{2}{|c|}{ Program Length (Years) } & 13 \\
\hline & & & & & & \multicolumn{2}{|c|}{ Averaged Yearly Cost } & 1,217 \\
\hline
\end{tabular}

Figure 21: Planning Costs 
At this point some assumptions are required. These are:

- That the definition of precisely what a master plan is in such circumstances is a matter for much discussion, so here "masterplan" is used in a very generic sense.

- That the planning teams require a "head office" team of twelve plus an additional person for every fifty teams, or part thereof.

- $\quad$ That the average salary per FTE is US\$100,000.

- That the average employment on-costs (leave, allowances, insurance, training, etc.) plus the operating expenses (office space, furniture, equipment, materials, utilities, etc.) total to an equivalent of $100 \%$ of salary cost per FTE.

- That wages and on costs increase due to inflation at $1 \%$ per annum for the duration of the project.

If these assumptions are correct, then figure 21 shows that the total cost of the planning program would be US\$15.8 T over 13 years, giving an average yearly cost of US\$1.2 B, including inflation. Obviously this estimate should be rigorously re-examined before an actual program is initiated, but it is reasonable to expect that a formal actuarial estimate would not differ from this quick estimate by more than plus or minus $15 \%$ from the estimate above, giving a range of between US\$1.0 B and US\$1.4 B.

\begin{tabular}{|c|c|c|c|c|c|c|c|}
\hline Project & Country & Designer/ Builder & $\begin{array}{l}\text { Projected } \\
\text { Population }\end{array}$ & $\begin{array}{c}\text { Estimated } \\
\text { Cost (US\$M) }\end{array}$ & $\begin{array}{c}\text { Duration } \\
\text { (years) }\end{array}$ & $\begin{array}{c}\text { Cost/Year/M } \\
\text { Pers } \\
\text { (US\$M/yr) }\end{array}$ & Notes \\
\hline Bahria Town Karachi & Pakistan & Bahria Town (Private) & $1,000,000$ & 1000 & 20 & 50 & $\begin{array}{l}\text { Assumed } \\
\text { duration }\end{array}$ \\
\hline Masdar & UAE & Foster + Partners & 47,500 & 20,000 & 20 & 21,053 & \\
\hline Ramciel & South Sudan & $\begin{array}{l}\text { Korea Land and } \\
\text { Housing } \\
\text { Corporation }\end{array}$ & 250,000 & 940 & 5 & 752 & $\begin{array}{l}\text { Assumed } \\
\text { population }\end{array}$ \\
\hline New Songdo City & South Korea & Kohn Pedersen Fox & 232,000 & 30,000 & 20 & 6,466 & \\
\hline \multicolumn{6}{|r|}{ Average $=$} & 7,080 & \\
\hline
\end{tabular}

Figure 22: Construction Cost Examples (from various websites)

Figure 22 shows that the construction cost of a sample of four new cities. Unfortunately, the available data is difficult to find and incomplete. Another complicating factor is that the range is very wide, from a cost per year per million persons of US\$50 M for Bahria, a gated community outside of Karachi, to US\$21 B for Masdar City, the sustainability demonstration project next to Abu Dhabi International Airport. Considering each of these in turn:

- Bahria is a large project, but it does benefit from proximity to Karachi, a major city with significant (if reportedly inadequate) infrastructure, therefore the total projected cost could be artificially low;

- Masdar has not grown at anything like the initially projected rate and was designed to a very high construction standard, so this cost is probably unrealistically high;

- Ramciel is a totally new city in a remote area in a country typical of the great arc of growth discussed above, but a master plan has not been finalised and the estimate shown is from 2012, so it is possibly a little low; and 
- New Songdo City is a high-rise city with a lot of new "smart city" technology and which has reportedly achieved only about one third of its projected occupancy (private site visit, 2018), and is therefore also probably unrealistically high for the type of project discussed here.

\begin{tabular}{|c|c|c|c|}
\hline Year & $\begin{array}{l}\text { Number of MP } \\
\text { Completed } \\
\text { (cumulative) }\end{array}$ & $\begin{array}{l}\text { Number of } \\
\text { Cities In } \\
\text { Detailed Design } \\
\text { \& Construction }\end{array}$ & $\begin{array}{l}\text { Cost/Year } \\
\text { (US\$M/yr) }\end{array}$ \\
\hline 2020 & 0 & 0 & $\$ 0$ \\
\hline 2021 & 0 & 0 & $\$ 0$ \\
\hline 2022 & 0 & 0 & $\$ 0$ \\
\hline 2023 & 7 & 7 & $\$ 7,000$ \\
\hline 2024 & 21 & 21 & $\$ 21,000$ \\
\hline 2025 & 49 & 49 & $\$ 49,000$ \\
\hline 2026 & 77 & 77 & $\$ 77,000$ \\
\hline 2027 & 133 & 133 & $\$ 133,000$ \\
\hline 2028 & 245 & 245 & $\$ 245,000$ \\
\hline 2029 & 357 & 357 & $\$ 357,000$ \\
\hline 2030 & 581 & 581 & $\$ 581,000$ \\
\hline 2031 & 1029 & 1029 & $\$ 1,029,000$ \\
\hline 2032 & 1477 & 1477 & $\$ 1,477,000$ \\
\hline 2033 & 2000 & 2000 & $\$ 2,000,000$ \\
\hline 2034 & & 2000 & $\$ 2,000,000$ \\
\hline 2035 & & 2000 & $\$ 2,000,000$ \\
\hline 2036 & & 2000 & $\$ 2,000,000$ \\
\hline 2037 & & 2000 & $\$ 2,000,000$ \\
\hline 2038 & & 2000 & $\$ 2,000,000$ \\
\hline 2039 & & 2000 & $\$ 2,000,000$ \\
\hline 2040 & & 2000 & $\$ 2,000,000$ \\
\hline 2041 & & 2000 & $\$ 2,000,000$ \\
\hline 2042 & & 2000 & $\$ 2,000,000$ \\
\hline 2043 & & 1993 & $\$ 1,993,000$ \\
\hline 2044 & & 1979 & $\$ 1,979,000$ \\
\hline 2045 & & 1951 & $\$ 1,951,000$ \\
\hline 2046 & & 1923 & $\$ 1,923,000$ \\
\hline 2047 & & 1867 & $\$ 1,867,000$ \\
\hline 2048 & & 1755 & $\$ 1,755,000$ \\
\hline 2049 & & 1643 & $\$ 1,643,000$ \\
\hline 2050 & & 1419 & $\$ 1,419,000$ \\
\hline 2051 & & 971 & $\$ 971,000$ \\
\hline 2052 & & 523 & $\$ 523,000$ \\
\hline 2053 & & 0 & $\$ 0$ \\
\hline \multirow[t]{2}{*}{30} & & Total & $\$ 40,000,000$ \\
\hline & & Average & $\$ 1,333,333$ \\
\hline
\end{tabular}

Figure 23: Construction Cost Calculator based on cost estimates for Ramciel, South Sudan

Considering the above it is proposed that a cost per year per million persons of US\$752 M for Ramciel be taken as starting point. Adding $30 \%$ as a worst case margin of error gives a tentative US\$1 B per year per million persons for the proposed 2000 new cities. 
The data on the projected time for detailed design and construction is more reliable, with all but Ramciel proposing a twenty-year program, so this time frame will be adopted for this study.

Given the dearth of reliable, published data on these and other new city projects, a much more extensive and thorough audit by a team that has the resources to visit a much larger sample of new city projects would be necessary before deciding upon an overall project estimate. While a wide margin of error should always be allowed for early estimates of individual project costs (because a completed master plan is required before reliable construction cost estimating is possible), averaging over 2000 projects should be reasonably accurate.

Table 5 shows that, assuming US\$1 B per year per million persons, construction costs start in the third year (2023), on completion of the first seven masterplans, at US\$7B a year, rising to US\$2 T a year in 2032, but deceasing from 2043 as the twenty-year initial city building phase is completed and each city become self-funding.

As anyone familiar with city building would expect, the estimated average planning cost of US\$1.4 B p.a. for thirteen years is miniscule compared to the estimated average detailed design and construction cost of US\$1.333 T p.a. for thirty years. Combined the total is US\$1.3344 T p.a. for thirty years, but this still rounds to US\$1.3 T p.a.

\subsection{Feasibility}

A preliminary cost of US\$1.3 T p.a. for thirty years demonstrates that the costs of planning and building 2000 new cities in the great arc of growth from West Africa through the Middle East, across Asia and into the Western Pacific is not beyond the G20 countries and their combined gross domestic product (GDP) of US\$78.4 T p.a. (in 2014), as illustrated in figure 24.

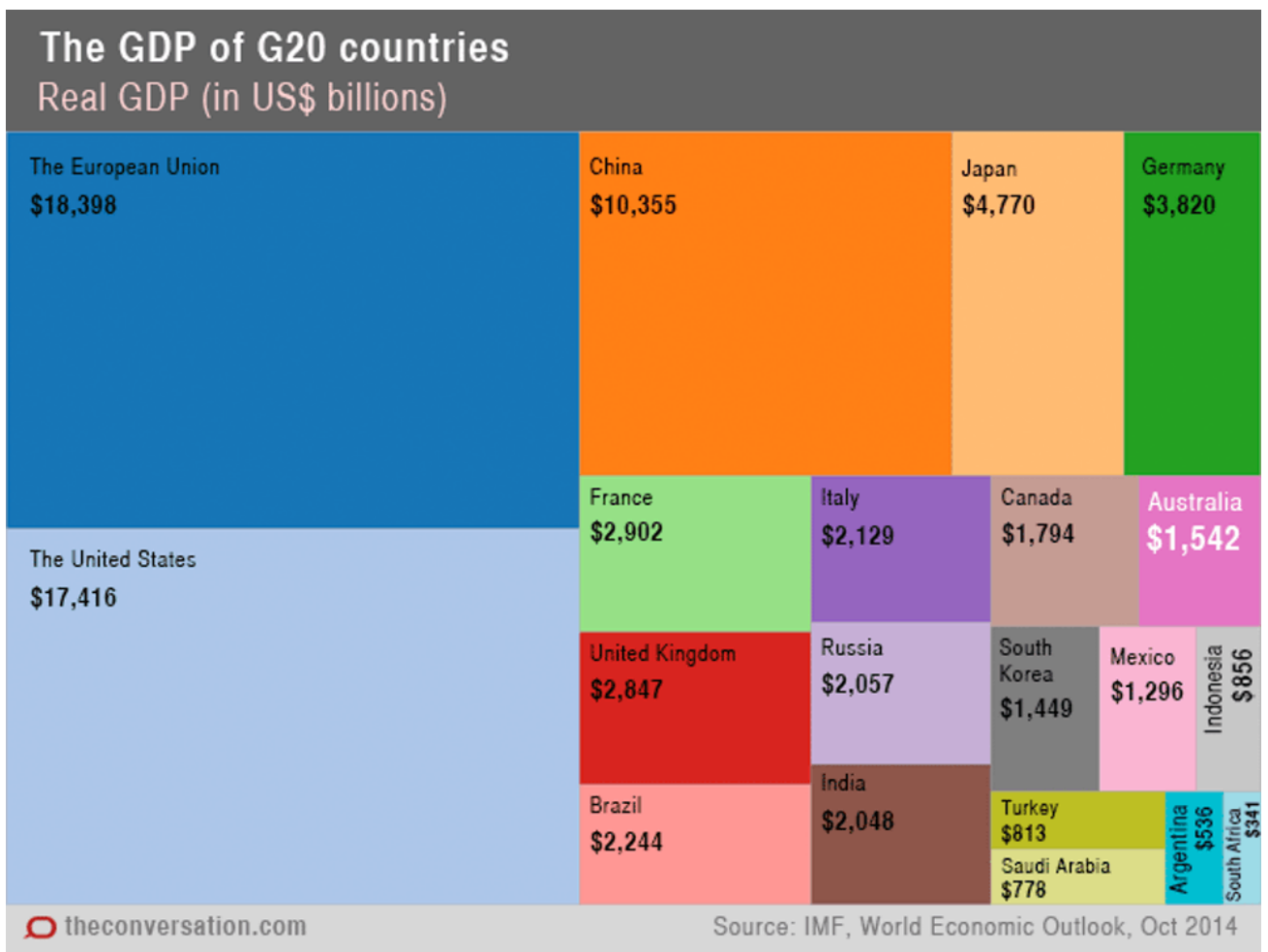

Figure 24: Gross Domestic Product (GDP) of the G20 countries in 2013-14 
However, while it is economically feasible for the G20 countries to allocate 1.7\% (US\$1.3 T out of US\$78.4 T) to solving rapid massive third-world urbanisation, it must be recognised that there is little likelihood of a political consensus to deliver that proportion of these countries' wealth in any one year, never mind a consistent policy over more than thirty years. Therefore, some other scenarios should be explored.

For example, if the design and construction costs of Bahria Town are accurate, and can be replicated across the Third World, then the average annual cost reduces to $\$ 67$ B p.a., which is only $0.085 \%$ of the G20's GDP. This is more realistic, but would still require the leadership of a Winston Churchill or Harry Truman to deliver a G20 wide consensus. A further difficulty is that the Bahria development model is premised on the purchase of properties by those with a middle-class income in that market, it will therefore not result in the emptying of dark satanic slums and impoverished shanty towns for a better future in master planned cities "dense with skyscrapers gleaming like the nylon bristles of a brand-new toothbrush". (Blake, 1804; Calvino, 2002, p. 308)

An alternate, free-market plan would require a private consortium to fund the planning effort (US\$1.4 B p.a. for thirteen years) and a single donation per city (spread over, say five years) of one billion US dollars (see Bahria Town Karachi in figure 22 above) to provide the initial infrastructure, possibly in return for naming rights. Perhaps the time will come when no selfrespecting multi-billionaire would be able to resist the attraction of having a city named after them! The cities would need to be charter cities, meaning that citizens purchase their citizenship with cash or labour. This requires that the master plans provide for the sort of urbanism that is sufficiently dense to create an economically sustainable city, but able to be built with basic building skills and materials, for example the sort of dense urbanism of the older European cities discussed above at section 6.

Of course, all options would benefit from the fact that the economy of cities is strongly circular, meaning that the initial cash injection generates jobs that pay wages that are spent on rent and goods within the city, which then generate profits that fund developments that generate jobs, etc. However, this requires good governance, a planning consideration that must also be addressed if the full benefits of planning, designing and building 2000 cities in the Third World are to be enjoyed by the citizens of those cities. This consideration could possibly benefit the charter cities option, provided that the internal governance of the city is strong enough to resist the interference of a corrupt national government.

Whichever model is adopted (and it could be a combination of one or more approaches) it is absolutely vital that these 2000 new cities provide very high-level triple-bottom-line outcomes. With good master planning they should start with good environmental outcomes and, as they should end migrations of desperation away from home countries, they have a head start in good social outcomes. However, there is little doubt that economic sustainability will require significant advances in the quality of governance in some of the countries in which these cities will be built. The issues raised in this simple statement are well beyond the scope of this paper, but must be addressed as part of this project. Given the time imperative it is necessary that such studies and proposals be conducted concurrently with the initial master planning phase and monitoring of the effectiveness of improvements in governance will, necessarily, last for many decades. 


\section{Conclusion}

Urban planners and designers are faced with the task of housing an additional three billion people in towns and cities by the year 2050. This is the equivalent of building six one millionperson cities every month for forty years. If climate change displaces another 200 million people the task will be that much greater. It is truly one of Alejandro Arevena's "3S Problems": a problem that is simultaneously large scale, requires a speedy response and must be dealt with by individuals or teams suffering a scarcity of means.

Compounding this problem, but also demonstrating that it might be part of the solution, the developing economies are generating large scale employment in their urban areas, some 900 million jobs in the thirty years from 1980 to 2010, but most of these jobs require the level of education that only a well-designed and managed large town or a city can provide.

China, since the 1980's, and India more recently have recognised this issue and responded with massive city building or urban improvement programs, but only one-third of the additional three billion new urban dwellers are expected to be in China, India and Nigeria, the remaining two-thirds will be in the countries around those countries: a massive arc stretching from West Africa, through the Middle East, across Asia and into the Pacific.

Clearly, if massive new urban areas are required very quickly, the planning process must be fast and reliable, and conducted within, or for, efficient, well-managed planning agencies. This requires not only the adoption of all that the new technologies have to offer, but also the development of a plan making paradigm that optimises the application of that technology in a way that produces good urbanism. In short a planning paradigm that avoids the possibility of "garbage in, garbage out".

The most significant advances in the understanding of urban areas and in the practice of producing good urban planning, and built outcomes, has been by the movement known as the New Urbanism. Three of these advances, the charrette, form based codes and transect planning are particularly relevant. In particular, the combination of transect-based planning and form based codes gives the opportunity to develop the New Urbanism further towards a systemisation that simultaneously enables localisation (perhaps, the core conundrum of urban planning across the ages). Success will enable automation of the approvals process with the possibility of some eighty percent of applications being approved, on-line, almost in an instant.

However, there is no time to lose waiting for such technological improvements, we need to start right now. The paper has demonstrated that if the funds and resources can be marshalled and fewer than one hundred planners and related professionals and support staff are deployed on seven new city projects within twelve months, then we can plan and build, from now to the year 2050, new urbanism sufficient to enable an additional three billion people to live, learn, work and play in good, new cities and towns.

\section{References}

Agrawal, A., Gans, J. and Goldfarb, A. (2018) Prediction Machines: The Simple Economics of Artificial Intelligence, Harvard Business Review Press. 
Arevena, A. (2014) "My architectural philosophy? Bring the community into the process", TED Talk, posted November 2014.

Batty, M. (1997) "Cellular Automata and Urban Form: A Primer", Journal of the American Planning Association, 63:2, 266 - 274)

Batty, M. (2013) The New Science of Cities, Cambridge, MA: MIT Press.

Blake, W. (1804) Milton, a Poem in 2 Books, London: W. Blake.

Borys, H., Talen, E., and Lambert, M. "The Codes Study" accessed at the website PlaceMakers (How We Teach> Form-Based Codes?> You're not alone).

Brito, L. and Smith, M. S. (2012) "State of the Planet Declaration", a communique issued following the Planet Under Pressure conference, London, 26-29 March 2012.

Brown, O. (2008) "Migration and Climate Change", International Organization for Migration: Research Series No. 31. Geneva: International Organization for Migration.

Caldicott, H. (2017) Sleepwalking to Armageddon - The Threat of Nuclear Annihilation, New York: The New Press.

Calvino, I. (1972) The Complete Cosmicomics, translated from the Italian by Martin McLaughlin, Tim Parks and William Weaver, Boston \& New York: Houghton Mifflin Harcourt, 2014.

Carter, K \& Moir, S (2012) "Diagrammatic Representations of Sustainability - a Review and Synthesis" at pp. 1479-89 of Smith, S D (ed.), Proceedings 28th Annual Association of Researchers in Construction Management (ARCOM) Conference, Edinburgh, UK, 35 September 2012.

Ceballos, G., Ehrlich, P. R. and Dirzo, R. (2017) "Biological annihilation via the ongoing sixth mass extinction signalled by vertebrate population loses and declines", PNAS Plus, 10 July 2017.

CEDA (2015) "Australia's Future Workforce", Committee for Economic Development of Australia (CEDA), 16 June 2015.

Centre for Applied Transect Studies (2016). Accessed at http://transect.org/index.html, June 2016.

Dennehy, J (2019) "UN chief says world faces fight for its life over climate change", The National, 30 June 2019 (Accessed at https://www.thenational.ae/uae/environment/ un-chief-says-world-faces-fight-for-its-life-over-climate-change-1.880863 on 19 July 2019).

Dobbs, R., Madgavkar, A., Barton, D., Labaye, E., Manyika, J., Roxburgh, C., Lund, S., Madhav, S. (2012) The World at Work: Jobs, pay and skills for 3.5 Billion people, for McKinsey Global Institute, June 2012.

Duany, A and Talen, A (2002) 'Transect Planning', Journal of the American Planning Association, 68:3, 245-266.

Duany, A., Sorlien, S. and Wright, W. (2008), The SmartCode - Version 9 and Manual, Miami: Centre for Applied Transect Studies. 
Furman, J., Holdren, J. P., Muñoz, C., Smith, M. and Zients, J. (2016) "Artificial Intelligence, Automation, and the Economy", Washington: Executive Office of the President, December 2016.

Gans, H. J. (1968) People and Plans: Essays on Urban Problems and Solutions, Basic Books.

Goldie, E. S. (2017) “The Jobless City - Revolution or Paradise?”, 53rd ISOCARP Joint Congress, Portland, OR, USA, 24-27 October 2017

Goodman, R. (1972) After the Planners, Simon \& Schuster.

Helmert, V. (2018) personal correspondence from Dr Volker Helmert of the Coordination Staff for Refugee Policy at the Federal Chancellery, Germany, 22 Oct 2018.

Howard, E. (1965) Garden Cities of To-Morrow, Faber \& Faber.

Jacobs, J. (1961) The Death and Life of Great American Cities, Random House.

Katz, P. (1994) The New Urbanism - Towards an Architecture of Community, McGraw Hill.

Kolbert, E. (2014) The Sixth Extinction - An Unnatural History, Bloomsbury, London.

Kunstler, J. H. (1993) The Geography of Nowhere: The Rise and Decline of America's ManMade Landscape, Simon \& Schuster.

Meadows, D. H., Meadows, D. L., Randers, J. and Behrens III, W. W. (1972) Limits to Growth, Universe Books.

Ortiz, Pedro B. (2014) The Art of Shaping the Metropolis, McGraw Hill Education.

Posin, D.Q. (1948) Mendeleev, The Story of a Great Chemist, New York: McGraw-Hill.

Prince of Wales, HRH The, Juniper, T. and Skelly, I. (2010) Harmony: A New Way of Looking at Our World, London: Blue Door.

Sorlien, S., image accessed from the website of the Centre for Applied Transect Studies (image library> rural-urban transects).

Stueteville, R. (2004) "CNU XII brings New Urbanism home to a city of urban innovation" A Public Square, Congress for the New Urbanism.

Talen, E. (2013) Charter of the New Urbanism, 2nd Edition, Congress for the New Urbanism.

UN News (2016) 'HABITAT III: UN conference agrees new urban development agenda creating sustainable, equitable cities for all'. Available at https://news.un.org/en/story/2016/10/543392-habitat-iii-un-conference-agreesnew-urban-development-agenda-creating (Accessed 19 July 2019).

United Nations (2014) "World Urbanization Prospects: The 2014 Revision", Department of Economic and Social Affairs, Population Division, United Nations (custom data available at http://www.un.org/en/development/desa/population/, (Accessed July 2015).

United Nations (2017) New Urban Agenda (English) 2017. (Adopted at the United Nations Conference on Housing and Sustainable Urban Development (Habitat III) in Quito, Ecuador, on 20 October 2016.) 
United Nations (1992) Report of the United Nations Conference on Environment and Development, Rio de Janeiro, 314 June 1992 (vol. I, Resolutions Adopted by the Conference), New York: United Nations.

Vikram, K. (2014) "Modi's vision of 'smart cities' takes shape as government commits to delivering first three hubs by 2019", Mail Online India, 29 August 2014.

Wadha, V. (2015) "We need a new version of Capitalism for the jobless future" The Washington Post, July 20th, 2015.

Wheeler, S M (2013) Planning for Sustainability (2nd edition), Routledge.

Wikipedia (2016a). Available at https://en.wikipedia.org/wiki/Johann_Heinrich_von_Thünen (Accessed on 25 June 2016).

Wikipedia (2016b). Available at https://en.wikipedia.org/wiki/Central_place_theory (Accessed on 25 June 2016).

Wikipedia (2019). Available at https://en.wikipedia.org/wiki/List_of_United_States_cities_ by_population_density (Accessed on 20 July 2019).

World Bank, (2014) "Urban China - Toward Efficient, Inclusive, and Sustainable Urbanization", World Bank.

Zolberg, A. R. (2006) A Nation by Design: Immigration Policy in the Fashioning of America, New York: Russell Sage Foundation. 